\title{
Results of an Inter-Laboratory Study of Glass Formulation for the Immobilization of Excess Plutonium
}

by

D. K. Peeler

Westinghouse Savannah River Company

Savannah River Site

Aiken, South Carolina 29808

T. F. Meaker

T. B. Edwards

J. D. Vienna

Pacific Northwest National Laboratory

D. B. Chamberlain

Argonne National Laboratory

DOE Contract No. DE-AC09-96SR18500

This paper was prepared in connection with work done under the above contract number with the U.S. Department of Energy. By acceptance of this paper, the publisher and/or recipient acknowledges the U.S. Government's right to retain a nonexclusive, royalty-free license in and to any copyright covering this paper, along with the right to reproduce and to authorize others to reproduce all or part of the copyrighted paper. 


\section{DISCLAIMER}

This report was prepared as an account of work sponsored by an agency of the United States Government. Neither the United States Government nor any agency thereof, nor any of their employees, makes any warranty, express or implied, or assumes any legal liability or responsibility for the accuracy, completeness, or usefulness of any information, apparatus, product or process disclosed, or represents that its use would not infringe privately owned rights. Reference herein to any specific commercial product, process or service by trade name, trademark, manufacturer, or otherwise does not necessarily constitute or imply its endorsement, recommendation, or favoring by the United States Government or any agency thereof. The views and opinions of authors expressed herein do not necessarily state or reflect those of the United States Government or any agency thereof.

This report has been reproduced directly from the best available copy.

Available for sale to the public, in paper, from: U.S. Department of Commerce, National Technical Information Service, 5285 Port Royal Road, Springfield, VA 22161

phone: (800) 553-6847

fax: (703) 605-6900

email: orders@ntis.fedworld.gov

online ordering: http://www.ntis.gov/ordering.htm

Available electronically at http://www.doe.gov/bridge

Available for a processing fee to U.S. Department of Energy and its contractors, in paper, from: U.S. Department of Energy, Office of Scientific and Technical Information, P.O. Box 62, Oak Ridge, TN 37831-0062

phone: (865)576-8401

fax: (865)576-5728

email: reports@adonis.osti.gov 


\section{DISCLAIMER}

Portions of this document may be illegible in electronic image products. Images are produced from the best available original document. 


$$
\text { SRT-PUM-97-0017 }
$$

\section{RESULTS OF AN INTER-LABORATORY STUDY OF GLASS FORMULATION FOR THE IMMOBILIZATION OF EXCESS PLUTONIUM (U)}

D.K. Peeler, T.F. Meaker, and T.B. Edwards Westinghouse Savannah River Company Savannah River Technology Center

J.D. Vienna and M.J. Schweiger Pacific Northwest National Laboratory

D.B. Chamberlain

Argonne National Laboratory

July 25, 1997

Westinghouse Savannah River Company Savannah River Site Aiken, SC 29808

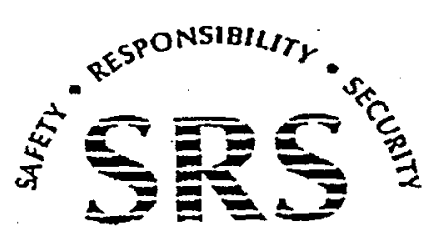


SRT-PUM-97-0017, Revision 0

Distribution Category: Unlimited

Keywords: plutonium, solubility, variability, thermal stability

Retention: Permanent

\section{RESULTS OF AN INTER-LABORATORY STUDY OF GLASS FORMULATION FOR THE IMMOBILIZATION OF EXCESS PLUTONIUM (U)}

D.K. Peeler, T.F. Meaker, and T.B. Edwards

Westinghouse Savannah River Company

Savannah River Technology Center

J.D. Vienna and M.J. Schweiger

Pacific Northwest National Laboratory

D.B. Chamberlain

Argonne National Laboratory

Westinghouse Savannah River Company

Savannah River Site

Aiken, SC 29808

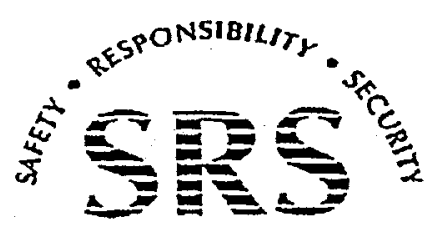

SAVANNAH RIVER SITE

PREPARED FOR THE U.S. DEPARTMENT OF ENERGY UNDER CONTRACT NO. DE-AC09-96SR18500 
SRT-PUM-97-0017

Approvals

David Kc. Pales

D.K. Peeler, SRTC

$\frac{7-25-97}{\text { Date }}$

T. F. Maker, sk TC

$\frac{7 / 25 / 92}{\text { bate }}$

Dor PF

D. F. Pickford, Technical Reviewer

(Verified technical review comments were dispositioned)

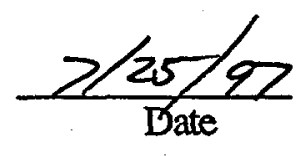

Eu boetzalater.

E. W. Holtzscheiter, Vitrification Technology Section

$\frac{7-25-97}{\text { Date }}$

Ewhetpahater

$\frac{7-25-97}{\text { Date }}$

3 


\section{EXECUTIVE SUMMARY}

In support of the Fissile Materials Disposition Program (FMDP), a lanthanide borosilicate (LaBS) glass system is being investigated to immobilize surplus weapons-usable plutonium and other Pu-bearing materials. In 1996, complete dissolution of $13.4 \mathrm{wt} \% \mathrm{PuO}_{2}$ was demonstrated in a LaBS glass when considering "pure" plutonium oxide as the feed material. The primary focus of the current study is to determine allowable loadings of feed streams containing different ratios of plutonium, uranium, and minor components ("impure" feeds) into the LaBS glass and to evaluate thermal stability with respect to the DWPF pour. This will result in the definition of a compositional envelope to treat the anticipated varied feed streams to produce a homogenous, thermally stable, durable glass waste form.

The incorporation of the highly variable "impure" feed streams in the LaBS glass is being investigated using a statistically designed test matrix. This test matrix was developed to address two technical issues: (1) the solubility of plutonium, uranium, and other minor components in the LaBS system and (2) the thermal stability of the glass when subjected to molten high level waste glass in the can-in-canister disposition option. The test matrix was designed based on the composition of the frit and the relative proportions of feed to frit that bounded a compositional envelope expected to satisfy process acceptance criteria. The trial glasses have feed loadings between 5 and $15 \mathrm{wt} \%$ which translates into plutonium and uranium loadings ranging from $2.4-15 \mathrm{wt} \%$ and $0.0-7.7 \mathrm{wt} \%$, respectively. The "minor" component mix consisted of anticipated the maximum concentrations of the minor components identified by the program. The minor components included: $\mathrm{Ca}, \mathrm{Mg}, \mathrm{Cl}, \mathrm{Ga}$, $\mathrm{Fe}, \mathrm{Cr}, \mathrm{Ni}, \mathrm{F}, \mathrm{K}, \mathrm{Na}, \mathrm{Mo}, \mathrm{Ta}, \mathrm{Ba}, \mathrm{W}$, and $\mathrm{Zn}$.

The results of the study have shown both complete solubility of all components $\left(\mathrm{PuO}_{2}\right.$, $\mathrm{UO}_{3}$, and the minor components) up to approximately $13.0 \mathrm{wt} \%$ combined loadings of $\mathrm{PuO}_{2}$ and $\mathrm{UO}_{3}$. Complete dissolution being defined based on the detection limits of the $\mathrm{XRD}$ unit $(0.3 \mathrm{wt} \%)$ and more sensitive SEM/EDS analysis. Samples to determine the homogeneity of the glass were selected from the bottom of the melt. These samples provide a very conservative estimate of the bulk and will reduce the defined processing region. Although very conservative sample selection limits the defined processing window, the following conclusion regarding solubility can be made based on the results of the intra-laboratory study:

- Complete dissolution of $\mathrm{PuO}_{2}$ and $\mathrm{UO}_{3}$ at combined loadings of $\leq 10 \mathrm{wt} \%$ has been demonstrated independent of the frit composition. This shows the flexibility of the LaBS system to allow for relatively major changes in the frit oxide components and still produce a homogeneous product. This was . consistently shown by the three independent laboratories.

- Complete dissolution of $\mathrm{PuO}_{2}+\mathrm{UO}_{3}$ with combined loadings $>10 \mathrm{wt} \%$ has been demonstrated. Maximum $\mathrm{PuO}_{2}$ and $\mathrm{UO}_{3}$ loadings are achievable through frit optimization.

- Complete dissolution of the minor components at their maximum concentrations and maximum loading ( $3.3 \mathrm{wt} \%$ in the glass) has been demonstrated in glasses with combined actinide loadings up to $13.3 \mathrm{wt} \%$ (L2-26). At higher heavy metal loadings, the minor components do not limit the fabrication of a homogeneous system. The limiting factor is $\mathrm{PuO}_{2}$ and the definition of an acceptable product. 
- $\mathrm{PuO}_{2}$ appears to be the limiting species for all 90 glasses. There was no indication of other species playing a major role in the definition of a homogeneous glass.

- Complete solubility of $\mathrm{UO}_{3}$ at the maximum loading $(7.7 \mathrm{wt} \%)$ has been demonstrated.

- The results are based on very conservative melt conditions and sample selection. Static melt conditions and analysis of a bottom sample are extremely conservative conditions from which to classify a melt as homogeneous. Even with these conservative conditions, a processing region can be defined which should expand if given the latitude to consider stirring and the bulk sample to define homogeneity.

LaBS glasses when subjected to a thermal profile can produce a partially devitrfied product. It has been observed that $\mathrm{PuO}_{2}$ devitrifies (with $\mathrm{Gd}_{2} \mathrm{O}_{3}, \mathrm{HfO}_{2}$, and $\mathrm{ZrO}_{2}$ partitioning with the $\mathrm{PuO}_{2}$ ) in some glasses. The development of $\mathrm{PuO}_{2}$ devitrification product is dependent upon the base frit composition, the total $\mathrm{PuO}_{2}$ loading, and/or the thermal treatment. Several LaBS glasses were determined to be homogeneous (no $\mathrm{PuO}_{2}$ crystals detected) after thermal treatment over the 2.4 to $11.6 \mathrm{wt} \%$ combined $\mathrm{PuO}_{2}+\mathrm{UO}_{3}$ loading range. The frit compositions of these glasses differ but a high $\mathrm{RE}_{2} \mathrm{O}_{3}$ content $(\geq 30 \mathrm{wt} \%$ ) was a general trend that suppressed $\mathrm{PuO}_{2}$ crystal formation. Although $\mathrm{PuO}_{2}$ devitrifies in some LaBS glasses upon thermal treatment, experimental data exists that show there is not a detrimental effect on the performance of the product (chemical durability) as measured by the Product Consistency Test (PCT). In fact the release of Pu between "as-fabricated" samples (complete solubility) and heat treated samples $\left(\mathrm{PuO}_{2}\right.$ precipitated) shows a reduction in the Pu release for the heat treated glass. 


\section{SRT-PUM-97-0017}

\section{INTRODUCTION}

Vitrification of highly radioactive material has been in production for over 20 years in Europe adn provides the basis for the long-term, safe disposal of excess plutonium is immobilization via vitrification in a lanthanide borosilicate (LaBS) glass. Previous efforts have successfully demonstrated complete solubility of up to $11.8 \mathrm{wt} \% \mathrm{Pu}(13.4 \mathrm{wt} \%$ $\mathrm{PuO}_{2}$ ) in the LaBS system.[1-9] These studies were based on initial programmatic assumptions that the incoming feed to immobilization was a "pure" $\mathrm{PuO}_{2}$ feed. Due to a change in programmatic direction, vitrification not only has to consider the "pure" $\mathrm{PuO}_{2}$ stream but also "impure" feed streams. These "impure" feeds have been identified by Diaz and Vienn $\mathrm{a}^{\dagger \dagger}$ with the $\mathrm{Pu}$ and $\mathrm{U}$ being the primary components. Also associated with these "impure" feeds are a host of other "minor" components. Table I lists the eight streams identified for the immobilization program and the components associated with each.

Borosilicate glass systems are known to accomodate compositional feed variability.[10,11] This is currently being demonstrated in the high-level waste programs at the Savannah River Site and West Valley Nuclear Services which are using borosilicate glasses to incorporate the wide compositional ranges of high-level liquid wastes (HLLW) to produce a durable glass waste form suitable for long-term disposal.[10-12] Hanford is also considering the use of a borosilicate glass for immobilizing HLLW.[11] Although tolerance to HLLW streams has been demonstrated in borosilicate systems, compositional differences do exist in the streams identified for the plutonium immobilization program. Therefore, the LaBS system must demonstrate that the expected variation of the "minor" components in the anticipated $\mathrm{Pu}$ feed streams can be fully incorporated and do not change the performance characteristics of the waste form while maintaining targeted $\mathrm{PuO}_{2}$ and $\mathrm{UO}_{3}^{*}$ loadings.

To address this issue, a statistically designed matrix was used to evaluate the ranges of expected feeds in terms of solubility (or homogeneity) and the effects on the final waste form. Edwards [13] designed a test matrix to demonstrate solubility of the identified feed streams for bounding conditions (extreme vertices) in the LaBS system. Similar studies have been used at SRS $[10,14]$ and Hanford [11] to bound the effects on potential HLLW feed variability on the waste form properties and processability.

\section{TEST MATRIX DESIGN BASIS}

Meaker et al [15] and Edwards [13] described two specific areas of concern for this study; solubility of the feed materials and devitrification potential of the resulting waste form. During processing, individual feed materials (i.e., $\mathrm{Pu}, \mathrm{U}$, and other identified minor components) must be fully incorporated (complete dissolution) into the glassy matrix. Therefore, the test matrix was designed to evaluate the limits of the LaBS system to fuilly incorporate a range of anticipated feeds and produce a homogeneous, durable glass product. The issue of devitrification is two-fold: (1) can a frit compositional space (or $\mathrm{PuO}_{2}$ loading) be identified that results in a homogeneous (crystal-free) LaBS glass after the Defense Waste Processing Facility (DWPF) pour (assuming can-in-canister alternative), and (2) if microstructural changes do occur in the glass upon heat treatment, what effect, if any, is there on the performance of the waste form. The impact of a microstructural change on performance is highly dependent upon the type and extent of crystallization [16] or the type of microstructure developed if considering amorphous phase separation.[17]

\footnotetext{
${ }^{\dagger \dagger}$ Letter to A. Caponiti from J. Diaz, "Impurities in Immobilization on feed streams", Dec. 4, 1996, DDIV-96-0020.

- Although the oxidation state of $U$ has not be determined in the $\mathrm{LaBS}$ glass, $\mathrm{UO}_{3}$ is being used as an assumption.
} 


$$
\text { SRT-PUM-97-0017 }
$$

To evaluate both solubility and devitrification potential, a compositional region was developed based on ranges of the feed streams and frit. The feed stream ranges were bounded assuming upper and lower limits for $\mathrm{Pu}, \mathrm{U}$, and the "minor" components. [13,15] Table I shows the final ranges for these primary variability study components. A bounding "worst-case scenario" is being considered in terms of the minor components with the maximum impurity levels of individual elements identified from each of the eight feed streams being used. These maximum levels defined an "upper" bound of each minor component associated with a constant "minor component" mix assuming a complex blending scheme. This constant mix was then varied from 0.0 to $3.3 \mathrm{wt} \%$ in the glass. If the LaBS glass can incorporate the maximum concentrations from each feed stream, under more realistic blending strategies then lower quantities of these minor components should be less of a concern.

Table I. Ranges for Major Oxide Components to be Evaluated in the Variability Study.

\begin{tabular}{|c|c|c|}
\cline { 2 - 3 } \multicolumn{1}{c|}{} & \multicolumn{2}{c|}{ Range After Loading } \\
\hline Feed Oxide & Low & High \\
\hline $\mathrm{PuO}_{2}$ & $2.4 \mathrm{wt} \%$ & $15.0 \mathrm{wt} \%$ \\
$\mathrm{UO}_{3}$ & $0.0 \mathrm{wt} \%$ & $7.7 \mathrm{wt} \%$ \\
Minor Components & $0.0 \mathrm{wt} \%$ & $3.3 \mathrm{wt} \%$ \\
\hline
\end{tabular}

The frit oxides ranges used in the test matrix are shown in Table II. Ranges given for the frit components are board enough to identify a thermally stable composition region. The low and high frit oxide values were determined based on previous work that defined the processing region for a "pure" actinide stream [2] and the LaBS frit utilized in the joint SRTC / PNNL studies that demonstrated complete solubility of $13.4 \mathrm{wt} \% \mathrm{PuO}_{2}$.[1] The latter frit is referred to throughout this report as the "SRTC/PNNL" LaBS frit.

Given high and low values, a geometric "centroid" can be determined for the frit compositional space. A comparison of the "centroid" frit composition to that of the "SRTC/PNNL" frit shows very similar compositions. The frit oxides ranges selected for the variability study are centered around the "SRTC/PNNL" frit. Therefore, high actinide solubilities with the "centroid" frit are expected (as observed in the "SRTC/PNNL" frit $13.4 \mathrm{wt} \% \mathrm{PuO}_{2}$ ). The primary chemical difference between these two frits is the $\mathrm{ZrO}_{2}$ content which is almost doubled in the "centroid" frit.

Table II. Frit Oxide Ranges of Variability Study.

\begin{tabular}{|c|c|c|c|c|}
\cline { 3 - 5 } \multicolumn{2}{c|}{} & \multicolumn{3}{c|}{ Frit Ranges for Variability Study } \\
\hline Frit Oxide (wt\%) & "SRTC/PNNL" & Low & "Centroid" & High \\
\hline $\mathrm{SiO}_{2}$ & 25.8 & 17.6 & 24.1 & 32.1 \\
$\mathrm{~B}_{2} \mathrm{O}_{3}$ & 10.4 & 7.1 & 9.8 & 12.9 \\
$\mathrm{Al}_{2} \mathrm{O}_{3}$ & 19.0 & 13.0 & 18.5 & 25.3 \\
$\mathrm{SrO}^{\mathrm{ZrO}}$ & 2.2 & 1.5 & 2.2 & 2.9 \\
$\mathrm{RE}_{2} \mathrm{O}_{3}$ & 1.2 & 0.8 & 2.1 & 3.4 \\
& 30.0 & 25.0 & 30.0 & 45.0 \\
\hline
\end{tabular}




$$
\text { SRT-PUM-97-0017 }
$$

Based on the feed (Table I) and frit (Table II) ranges, a representative glass compositional space was defined from which a statistically designed collection of glass compositions were chosen for evaluation.[13] The glass compositional space was developed using the available information on potential plutonium feed streams, a target loading of the representative feeds in the glass of 5 to $15 \mathrm{wt} \%$, six frit components and their compositional ranges. Statistical methods were used to develop a collection of 90 glass compositions. The glasses were fabricated as part of an inter-laboratory testing program in which three laboratories (SRTC, PNNL, and ANL) participated. Thirty glasses were fabricated and evaluated at each laboratory for solubility (homogeneity) and thermal stability. The "centroid" glass composition was common to all three laboratories in an effort to show if the experimental procedures and/or the analytical techniques used to evaluate both complete solubility and thermal stability were consistent from lab-to-lab. Standard experimental procedures were written to minimize variability between the three laboratories.[18]

Table III - V show the thirty glass compositions that were evaluated for each laboratory. The L1, L2, and L3 glass series correspond to the three participating laboratories: SRTC, PNNL, and ANL respectively. For example, L2-03 is the third glass composition fabricated and evaluated by PNNL. L3-30 is the thirtieth glass composition fabricated and evaluated by ANL. L1-21, L2-07, and L3-11 are the common "centroid" glasses. Figure 1 shows a schematic of the defined compositional space in which solubility and thermal stability were to be evaluated. At the center of the defined space are both the "centroid" and "SRTC/PNNL" frit compositions.

Again, the purpose of this study is two fold: (1) evaluate the solubility of anticipated feed streams in the LaBS system and (2) evaluate a frit composition space for devitrification potential. It was not the intent of this study to identify a specific frit composition. In fact, the designed 90 glasses all have different frit compositions. However, the design will allow for a region in frit compositional space to be determined in which solubility is maximized and thermal stability is achieved. (Again, the 90 glasses defined by the variability study have different base frit compositions therefore direct comparisons of the maximum loading or thermal stability should be used with caution when comparing the performance among glasses). 


$$
\text { SRT-PUM-97-0017 }
$$

Table III. Glass Compositions (L1 Series) Tested at SRTC.

Values are given as weight fractions.

\begin{tabular}{|c|c|c|c|c|c|c|c|c|c|c|c|}
\hline 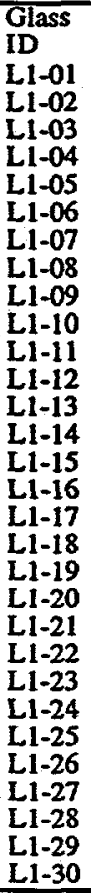 & $\begin{array}{l}\mathrm{PuO}_{2} \\
0.07975 \\
0.07268 \\
0.08700 \\
0.10275 \\
0.11850 \\
0.10275 \\
0.02400 \\
0.02400 \\
0.02400 \\
0.02400 \\
0.10275 \\
0.15000 \\
0.02400 \\
0.08700 \\
0.07975 \\
0.08700 \\
0.02400 \\
0.02400 \\
0.15000 \\
0.15000 \\
0.08076 \\
0.02400 \\
0.02400 \\
0.02400 \\
0.05550 \\
0.05550 \\
0.11850 \\
0.08700 \\
0.10275 \\
0.15000\end{array}$ & $\begin{array}{l}U O_{3} \\
0.03247 \\
0.03601 \\
0.07700 \\
0.01930 \\
0.03850 \\
0.01930 \\
0.03850 \\
0.07700 \\
0.03850 \\
0.00000 \\
0.03855 \\
0.00000 \\
0.00000 \\
0.03850 \\
0.03247 \\
0.03855 \\
0.00000 \\
0.07700 \\
0.00000 \\
0.07700 \\
0.03514 \\
0.07700 \\
0.03850 \\
0.07700 \\
0.00000 \\
0.01930 \\
0.03850 \\
0.01930 \\
0.05780 \\
0.00000\end{array}$ & $\begin{array}{l}\text { Minor } \\
\text { Comp. } \\
0.01090 \\
0.02151 \\
0.03300 \\
0.01645 \\
0.01650 \\
0.01645 \\
0.00000 \\
0.00000 \\
0.00000 \\
0.00000 \\
0.02470 \\
0.03300 \\
0.00000 \\
0.01650 \\
0.01798 \\
0.02470 \\
0.03300 \\
0.00000 \\
0.00000 \\
0.00000 \\
0.01642 \\
0.01650 \\
0.03300 \\
0.03300 \\
0.03300 \\
0.00820 \\
0.01650 \\
0.00820 \\
0.02305 \\
0.01650\end{array}$ & $\begin{array}{l}\text { Total } \\
\text { Feed } \\
0.12312 \\
0.13020 \\
0.19700 \\
0.13850 \\
0.17350 \\
0.13850 \\
0.06250 \\
0.10100 \\
0.06250 \\
0.02400 \\
0.16600 \\
0.18300 \\
0.02400 \\
0.14200 \\
0.13020 \\
0.15025 \\
0.05700 \\
0.10100 \\
0.15000 \\
0.22700 \\
0.13232 \\
0.11750 \\
0.09550 \\
0.13400 \\
0.08850 \\
0.08300 \\
0.17350 \\
0.11450 \\
0.18360 \\
0.16650\end{array}$ & $\begin{array}{l}\mathrm{SiO} 2 \\
0.22744 \\
0.22390 \\
0.24850 \\
0.21220 \\
0.17600 \\
0.25730 \\
0.17600 \\
0.32100 \\
0.24850 \\
0.32100 \\
0.21220 \\
0.17600 \\
0.17600 \\
0.24850 \\
0.22390 \\
0.24555 \\
0.17600 \\
0.17600 \\
0.31800 \\
0.17600 \\
0.24071 \\
0.24850 \\
0.32100 \\
0.32000 \\
0.32100 \\
0.28470 \\
0.17600 \\
0.28130 \\
0.21220 \\
0.32100\end{array}$ & $\begin{array}{l}\mathrm{B}_{2} \mathrm{O}_{3} \\
0.09187 \\
0.09010 \\
0.10000 \\
0.11450 \\
0.10000 \\
0.08550 \\
0.12900 \\
0.07100 \\
0.10000 \\
0.07100 \\
0.09430 \\
0.07100 \\
0.12900 \\
0.07100 \\
0.09010 \\
0.08550 \\
0.07100 \\
0.12900 \\
0.12900 \\
0.07100 \\
0.09837 \\
0.10000 \\
0.07100 \\
0.12900 \\
0.07100 \\
0.08550 \\
0.12900 \\
0.08550 \\
0.08550 \\
0.07100\end{array}$ & $\begin{array}{l}\mathrm{Al}_{2} \mathrm{O}_{3} \\
0.17060 \\
0.17060 \\
0.15575 \\
0.16875 \\
0.19150 \\
0.16070 \\
0.19150 \\
0.13000 \\
0.25300 \\
0.25300 \\
0.16070 \\
0.25300 \\
0.13000 \\
0.25300 \\
0.17060 \\
0.16070 \\
0.13000 \\
0.25300 \\
0.13000 \\
0.13000 \\
0.18478 \\
0.19150 \\
0.18475 \\
0.13000 \\
0.18825 \\
0.17475 \\
0.13000 \\
0.16070 \\
0.16070 \\
0.13000\end{array}$ & $\begin{array}{l}\text { SrO } \\
0.01960 \\
0.01960 \\
0.01500 \\
0.01850 \\
0.02900 \\
0.01850 \\
0.01500 \\
0.01500 \\
0.01500 \\
0.02900 \\
0.02200 \\
0.01500 \\
0.02900 \\
0.02750 \\
0.01960 \\
0.01850 \\
0.01500 \\
0.01500 \\
0.01500 \\
0.02900 \\
0.02218 \\
0.02900 \\
0.01500 \\
0.02900 \\
0.02900 \\
0.02550 \\
0.02900 \\
0.01850 \\
0.01850 \\
0.02200\end{array}$ & $\begin{array}{l}\mathrm{ZO}_{2} \\
0.01748 \\
0.01660 \\
0.03375 \\
0.02255 \\
0.00800 \\
0.01450 \\
0.00800 \\
0.03400 \\
0.02100 \\
0.00800 \\
0.01450 \\
0.03400 \\
0.03400 \\
0.00800 \\
0.01660 \\
0.01450 \\
0.00800 \\
0.00800 \\
0.00800 \\
0.00800 \\
0.02080 \\
0.03400 \\
0.03400 \\
0.00800 \\
0.02100 \\
0.02155 \\
0.03400 \\
0.01450 \\
0.01450 \\
0.00800\end{array}$ & $\begin{array}{l}\text { Rare } \\
\text { Earths } \\
0.34988 \\
0.34900 \\
0.25000 \\
0.32500 \\
0.32200 \\
0.32500 \\
0.41800 \\
0.32800 \\
0.30000 \\
0.29400 \\
0.33030 \\
0.26800 \\
0.47800 \\
0.25000 \\
0.34900 \\
0.32500 \\
0.54300 \\
0.31800 \\
0.25000 \\
0.35900 \\
0.30085 \\
0.27950 \\
0.27875 \\
0.25000 \\
0.28125 \\
0.32500 \\
0.32850 \\
0.32500 \\
0.32500 \\
0.28150\end{array}$ & $\begin{array}{l}\text { Total } \\
\text { Frit } \\
0.87687 \\
0.86980 \\
0.80300 \\
0.86150 \\
0.82650 \\
0.86150 \\
0.93750 \\
0.89900 \\
0.93750 \\
0.97600 \\
0.83400 \\
0.81700 \\
0.97600 \\
0.85800 \\
0.86980 \\
0.84975 \\
0.94300 \\
0.89900 \\
0.85000 \\
0.77300 \\
0.86768 \\
0.88250 \\
0.90450 \\
0.86600 \\
0.91150 \\
0.91700 \\
0.82650 \\
0.88550 \\
0.81640 \\
0.83350\end{array}$ \\
\hline
\end{tabular}




$$
\text { SRT-PUM-97-0017 }
$$

Table IV. Glass Compositions (L2 Series) Tested at PNNL.

Values are given as weight fractions.

\begin{tabular}{|c|c|c|c|c|c|c|c|c|c|c|c|}
\hline $\begin{array}{l}\text { Glass } \\
\text { ID } \\
\text { L2-01 } \\
\text { L2-02 } \\
\text { L2-03 } \\
\text { L2-04 } \\
\text { L2-05 } \\
\text { L2-06 } \\
\text { L2-07 } \\
\text { L2-08 } \\
\text { L2-09 } \\
\text { L2-10 } \\
\text { L2-11 } \\
\text { L2-12 } \\
\text { L2-13 } \\
\text { L2-14 } \\
\text { L2-15 } \\
\text { L2-16 } \\
\text { L2-17 } \\
\text { L2-18 } \\
\text { L2-19 } \\
\text { L2-20 } \\
\text { L2-21 } \\
\text { L2-22 } \\
\text { L2-23 } \\
\text { L2-24 } \\
\text { L2-25 } \\
\text { L2-26 } \\
\text { L2-27 } \\
\text { L2-28 } \\
\text { L2-29 } \\
\text { L2-30 }\end{array}$ & $\begin{array}{l}\mathrm{PuO}_{2} \\
0.02400 \\
0.15000 \\
0.02400 \\
0.11850 \\
0.08700 \\
0.07975 \\
0.08076 \\
0.02400 \\
0.08700 \\
0.02400 \\
0.05550 \\
0.15000 \\
0.11850 \\
0.15000 \\
0.15000 \\
0.07975 \\
0.08700 \\
0.08700 \\
0.02400 \\
0.11400 \\
0.07125 \\
0.14200 \\
0.06560 \\
0.05550 \\
0.02400 \\
0.05550 \\
0.02400 \\
0.05550 \\
0.05550 \\
0.05550\end{array}$ & $\begin{array}{l}U_{3} \\
0.07700 \\
0.07700 \\
0.00000 \\
0.03850 \\
0.03850 \\
0.03247 \\
0.03514 \\
0.07700 \\
0.01930 \\
0.03850 \\
0.05780 \\
0.00000 \\
0.03850 \\
0.00000 \\
0.07700 \\
0.02540 \\
0.01930 \\
0.00000 \\
0.00000 \\
0.00000 \\
0.03855 \\
0.07700 \\
0.03850 \\
0.03855 \\
0.00000 \\
0.07700 \\
0.03850 \\
0.01930 \\
0.03855 \\
0.03850\end{array}$ & $\begin{array}{l}\text { Minor } \\
\text { Comp } \\
0.03300 \\
0.00000 \\
0.03300 \\
0.00000 \\
0.01650 \\
0.01090 \\
0.01642 \\
0.00000 \\
0.00820 \\
0.03300 \\
0.02470 \\
0.00000 \\
0.03300 \\
0.00000 \\
0.00000 \\
0.02210 \\
0.01645 \\
0.03300 \\
0.01650 \\
0.03300 \\
0.02470 \\
0.03300 \\
0.01090 \\
0.02470 \\
0.00000 \\
0.03300 \\
0.01650 \\
0.02470 \\
0.01645 \\
0.00000\end{array}$ & $\begin{array}{l}\text { Total } \\
\text { Feed } \\
0.13400 \\
0.22700 \\
0.05700 \\
0.15700 \\
0.14200 \\
0.12312 \\
0.13232 \\
0.10100 \\
0.11450 \\
0.09550 \\
0.13800 \\
0.15000 \\
0.19000 \\
0.15000 \\
0.22700 \\
0.12725 \\
0.12275 \\
0.12000 \\
0.04050 \\
0.14700 \\
0.13450 \\
0.25200 \\
0.11500 \\
0.11875 \\
0.02400 \\
0.16550 \\
0.07900 \\
0.09950 \\
0.11050 \\
0.09400\end{array}$ & $\begin{array}{l}\mathrm{SiO}_{2} \\
0.24300 \\
0.29900 \\
0.17600 \\
0.24850 \\
0.24850 \\
0.22390 \\
0.24071 \\
0.32100 \\
0.21220 \\
0.17600 \\
0.25780 \\
0.17600 \\
0.32100 \\
0.32100 \\
0.17600 \\
0.22685 \\
0.21220 \\
0.32100 \\
0.32100 \\
0.32100 \\
0.26130 \\
0.17600 \\
0.23910 \\
0.27705 \\
0.17600 \\
0.24850 \\
0.17600 \\
0.24845 \\
0.24845 \\
0.32100\end{array}$ & $\begin{array}{l}\mathrm{B}_{2} \mathrm{O}_{3} \\
0.07100 \\
0.07100 \\
0.07100 \\
0.07100 \\
0.12900 \\
0.09718 \\
0.09837 \\
0.12900 \\
0.10000 \\
0.12900 \\
0.08550 \\
0.12900 \\
0.07850 \\
0.07100 \\
0.07100 \\
0.09010 \\
0.08550 \\
0.12900 \\
0.10000 \\
0.12900 \\
0.08550 \\
0.12900 \\
0.09010 \\
0.08550 \\
0.12900 \\
0.10000 \\
0.12900 \\
0.08550 \\
0.10000 \\
0.07100\end{array}$ & $\begin{array}{l}\mathrm{Al}_{2} \mathrm{O}_{3} \\
0.25300 \\
0.13000 \\
0.13000 \\
0.13000 \\
0.13000 \\
0.17060 \\
0.18478 \\
0.13000 \\
0.21530 \\
0.19150 \\
0.16070 \\
0.25300 \\
0.13375 \\
0.13000 \\
0.13000 \\
0.17060 \\
0.22155 \\
0.13000 \\
0.19150 \\
0.13000 \\
0.16070 \\
0.13000 \\
0.17060 \\
0.16070 \\
0.13000 \\
0.13000 \\
0.25300 \\
0.20855 \\
0.17187 \\
0.24100\end{array}$ & $\begin{array}{l}S R O \\
0.01500 \\
0.01500 \\
0.02900 \\
0.02900 \\
0.01500 \\
0.01960 \\
0.02218 \\
0.02900 \\
0.01850 \\
0.02200 \\
0.01850 \\
0.02900 \\
0.01875 \\
0.02900 \\
0.01500 \\
0.01960 \\
0.01850 \\
0.02900 \\
0.02200 \\
0.01500 \\
0.01850 \\
0.02900 \\
0.01960 \\
0.01850 \\
0.01500 \\
0.02900 \\
0.02900 \\
0.01850 \\
0.02550 \\
0.01500\end{array}$ & $\begin{array}{l}\mathrm{ZOO}_{2} \\
0.03400 \\
0.00800 \\
0.00800 \\
0.00800 \\
0.02100 \\
0.01660 \\
0.02080 \\
0.00800 \\
0.01450 \\
0.00800 \\
0.01450 \\
0.00800 \\
0.00800 \\
0.03400 \\
0.00800 \\
0.01660 \\
0.01450 \\
0.01450 \\
0.02100 \\
0.00800 \\
0.01450 \\
0.03400 \\
0.01660 \\
0.01450 \\
0.03400 \\
0.02100 \\
0.00800 \\
0.01450 \\
0.01450 \\
0.00800\end{array}$ & $\begin{array}{l}\text { Rare } \\
\text { Earths } \\
0.25000 \\
0.25000 \\
0.52900 \\
0.35650 \\
0.31450 \\
0.34900 \\
0.30085 \\
0.28200 \\
0.32500 \\
0.37800 \\
0.32500 \\
0.25500 \\
0.25000 \\
0.26500 \\
0.37300 \\
0.34900 \\
0.32500 \\
0.25650 \\
0.30400 \\
0.25000 \\
0.32500 \\
0.25000 \\
0.34900 \\
0.32500 \\
0.49200 \\
0.30600 \\
0.32600 \\
0.32500 \\
0.32917 \\
0.25000\end{array}$ & $\begin{array}{l}\text { Total } \\
\text { Frit } \\
0.86600 \\
0.77300 \\
0.94300 \\
0.84300 \\
0.85800 \\
0.87688 \\
0.86768 \\
0.89900 \\
0.88550 \\
0.90450 \\
.86200 \\
0.85000 \\
0.81000 \\
0.85000 \\
0.77300 \\
0.87275 \\
0.87725 \\
0.88000 \\
0.95950 \\
0.85300 \\
0.86550 \\
0.74800 \\
0.88500 \\
0.88125 \\
0.97600 \\
0.83450 \\
0.92100 \\
0.90050 \\
0.88949 \\
0.90600\end{array}$ \\
\hline
\end{tabular}




$$
\text { SRT-PUM- } 97-0017
$$

Table V. Glass Compositions (L3 Series) Tested at ANL.

Values are given as weight fractions.

\begin{tabular}{|c|c|c|c|c|c|c|c|c|c|c|c|}
\hline $\begin{array}{l}\text { Glass } \\
\text { ID } \\
\text { L3-01 } \\
\text { L3-02 } \\
\text { L3-03 } \\
\text { L3-04 } \\
\text { L3-05 } \\
\text { L3-06 } \\
\text { L3-07 } \\
\text { L3-08 } \\
\text { L3-09 } \\
\text { L3-10 } \\
\text { L3-11 } \\
\text { L3-12 } \\
\text { L3-13 } \\
\text { L3-14 } \\
\text { L3-15 } \\
\text { L3-16 } \\
\text { L3-17 } \\
\text { L3-18 } \\
\text { L3-19 } \\
\text { L3-20 } \\
\text { L3-21 } \\
\text { L3-22 } \\
\text { L3-23 } \\
\text { L3-24 } \\
\text { L3-25 } \\
\text { L3-26 } \\
\text { L3-27 } \\
\text { L3-28 } \\
\text { L3-29 } \\
\text { L3-30 }\end{array}$ & $\begin{array}{l}\mathrm{PuO}_{2} \\
0.08700 \\
0.02400 \\
0.11850 \\
0.06560 \\
0.05550 \\
0.09390 \\
0.02400 \\
0.05550 \\
0.11850 \\
0.02400 \\
0.08076 \\
0.08700 \\
0.05550 \\
0.08700 \\
0.02400 \\
0.05550 \\
0.07125 \\
0.15000 \\
0.08700 \\
0.10700 \\
0.15000 \\
0.11850 \\
0.02400 \\
0.10275 \\
0.06560 \\
0.15000 \\
0.02400 \\
0.02400 \\
0.10275 \\
0.08700\end{array}$ & $\begin{array}{l}\mathrm{UO}_{3} \\
0.05780 \\
0.00000 \\
0.03850 \\
0.02540 \\
0.03850 \\
0.02540 \\
0.07700 \\
0.00000 \\
0.00000 \\
0.00000 \\
0.03514 \\
0.05780 \\
0.03850 \\
0.03850 \\
0.00000 \\
0.01930 \\
0.01930 \\
0.00000 \\
0.00000 \\
0.00000 \\
0.07700 \\
0.03850 \\
0.03850 \\
0.05780 \\
0.03850 \\
0.07700 \\
0.07700 \\
0.07700 \\
0.03855 \\
0.01930\end{array}$ & $\begin{array}{l}\text { Minor } \\
\text { Comp } \\
0.01645 \\
0.03300 \\
0.01650 \\
0.01650 \\
0.00000 \\
0.01090 \\
0.03300 \\
0.03300 \\
0.01650 \\
0.00000 \\
0.01642 \\
0.02470 \\
0.03300 \\
0.00000 \\
0.00000 \\
0.00820 \\
0.00820 \\
0.03300 \\
0.03300 \\
0.00000 \\
0.00000 \\
0.01650 \\
0.03300 \\
0.00820 \\
0.02210 \\
0.03300 \\
0.03300 \\
0.00000 \\
0.01645 \\
0.02470\end{array}$ & $\begin{array}{l}\text { Total } \\
\text { Feed } \\
0.16125 \\
0.05700 \\
0.17350 \\
0.10750 \\
0.09400 \\
0.13020 \\
0.13400 \\
0.08850 \\
0.13500 \\
0.02400 \\
0.13232 \\
0.16950 \\
0.12700 \\
0.12550 \\
0.02400 \\
0.08300 \\
0.09875 \\
0.18300 \\
0.12000 \\
0.10700 \\
0.22700 \\
0.17350 \\
0.09550 \\
0.16875 \\
0.12620 \\
0.26000 \\
0.13400 \\
0.10100 \\
0.15775 \\
0.13100\end{array}$ & $\begin{array}{l}\mathrm{SiO}_{2} \\
0.22338 \\
0.17600 \\
0.24850 \\
0.22390 \\
0.24850 \\
0.22390 \\
0.17600 \\
0.32100 \\
0.24850 \\
0.17600 \\
0.24071 \\
0.22630 \\
0.32100 \\
0.32100 \\
0.17600 \\
0.28470 \\
0.28470 \\
0.17600 \\
0.32100 \\
0.32100 \\
0.17600 \\
0.24850 \\
0.32100 \\
0.22705 \\
0.22790 \\
0.17600 \\
0.32100 \\
0.17600 \\
0.22513 \\
0.26480\end{array}$ & $\begin{array}{l}\mathrm{B}_{2} \mathrm{O}_{3} \\
0.09668 \\
0.07100 \\
0.07100 \\
0.10990 \\
0.10000 \\
0.09010 \\
0.12900 \\
0.10000 \\
0.12900 \\
0.07100 \\
0.09837 \\
0.08550 \\
0.07100 \\
0.07100 \\
0.12900 \\
0.11360 \\
0.08550 \\
0.07100 \\
0.12900 \\
0.12900 \\
0.07100 \\
0.07100 \\
0.10000 \\
0.08550 \\
0.09010 \\
0.12900 \\
0.07100 \\
0.07100 \\
0.09196 \\
0.08550\end{array}$ & $\begin{array}{l}\mathrm{Al}_{2} \mathrm{O}_{3} \\
0.16070 \\
0.13000 \\
0.23400 \\
0.17205 \\
0.19150 \\
0.17060 \\
0.24800 \\
0.17375 \\
0.13000 \\
0.25300 \\
0.18478 \\
0.16070 \\
0.13000 \\
0.16975 \\
0.25300 \\
0.16070 \\
0.16070 \\
0.25300 \\
0.15700 \\
0.13000 \\
0.22700 \\
0.18200 \\
0.13000 \\
0.16070 \\
0.17060 \\
0.13000 \\
0.20100 \\
0.13000 \\
0.16070 \\
0.16070\end{array}$ & $\begin{array}{l}\text { SrO } \\
0.01850 \\
0.01500 \\
0.01500 \\
0.01960 \\
0.02900 \\
0.01960 \\
0.02900 \\
0.01500 \\
0.02900 \\
0.01500 \\
0.02218 \\
0.01850 \\
0.01500 \\
0.01500 \\
0.01500 \\
0.01850 \\
0.02550 \\
0.02900 \\
0.01500 \\
0.02900 \\
0.01500 \\
0.02200 \\
0.02900 \\
0.01850 \\
0.01960 \\
0.01500 \\
0.01500 \\
0.02900 \\
0.02496 \\
0.01850\end{array}$ & $\begin{array}{l}\mathrm{ZO}_{2} \\
0.01450 \\
0.03400 \\
0.00800 \\
0.01660 \\
0.02100 \\
0.01660 \\
0.03400 \\
0.00800 \\
0.00800 \\
0.03400 \\
0.02080 \\
0.01450 \\
0.02100 \\
0.02100 \\
0.00800 \\
0.01450 \\
0.01985 \\
0.00800 \\
0.00800 \\
0.03400 \\
0.03400 \\
0.00800 \\
0.03400 \\
0.01450 \\
0.01660 \\
0.00800 \\
0.00800 \\
0.00800 \\
0.01450 \\
0.01450\end{array}$ & $\begin{array}{l}\text { Rare } \\
\text { Earths } \\
0.32500 \\
0.51700 \\
0.25000 \\
0.35045 \\
0.31600 \\
0.34900 \\
0.25000 \\
0.29375 \\
0.32050 \\
0.42700 \\
0.30085 \\
0.32500 \\
0.31500 \\
0.27675 \\
0.39500 \\
0.32500 \\
0.32500 \\
0.28000 \\
0.25000 \\
0.25000 \\
0.25000 \\
0.29500 \\
0.29050 \\
0.32500 \\
0.34900 \\
0.28200 \\
0.25000 \\
0.48500 \\
0.32500 \\
0.32500\end{array}$ & $\begin{array}{l}\text { Total } \\
\text { Frit } \\
0.83876 \\
0.94300 \\
0.82650 \\
0.89250 \\
0.90600 \\
0.86980 \\
0.86600 \\
0.91150 \\
0.86500 \\
0.97600 \\
0.86768 \\
0.83050 \\
0.87300 \\
0.87450 \\
0.97600 \\
0.91700 \\
0.90125 \\
0.81700 \\
0.88000 \\
0.89300 \\
0.77300 \\
0.82650 \\
0.90450 \\
0.83125 \\
0.87380 \\
0.74000 \\
0.86600 \\
0.89900 \\
0.84225 \\
0.86900\end{array}$ \\
\hline
\end{tabular}




$$
\text { SRT-PUM-97-0017 }
$$

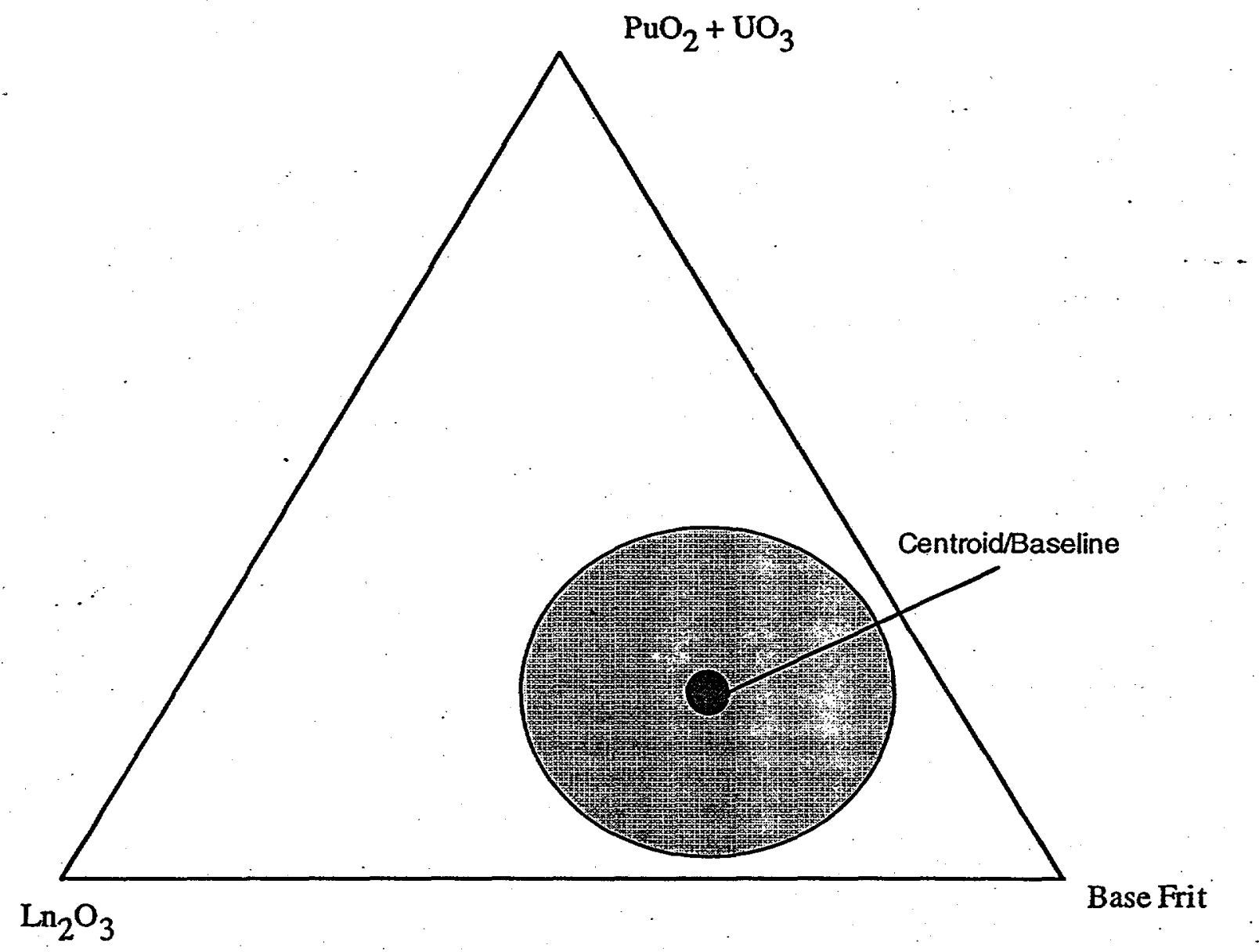

Figure 1. Schematic showing compositional region to be evaluated.

"Baseline" refers to the SRTC/PNNL frit. 


\section{SRT-PUM-97-00/7}

\section{EXPERIMENTAL PROCEDURES}

Fabrication and Solubility Evaluation

The test matrix glasses were fabricated by mixing the specified pre-fabricated frit (including $\mathrm{UO}_{3}$ and the "minor" components) with the appropriate $\mathrm{PuO}_{2}$ concentration and processing under "isothermal" conditions at $1500^{\circ} \mathrm{C}$ for 4 hours. After the four hour residence time, a representative sample from the bottom of the melt was obtained for the solubility analysis.

A bottom sample was chosen because of previous experience with LaBS glasses in which a targeted $\mathrm{PuO}_{2}$ loading exceeding the $\mathrm{PuO}_{2}$ solubility limit. In these glasses and under static melt conditions a distinct layer of undissolved oxide on the bottom of the melt is observed. If visual observations did not detect undissolved material on the bottom (or within the bulk), $X$-ray diffraction (XRD) and/or scanning electron microscopy (SEM) with energy dispersive spectroscopy (EDS) were used as the analytical tools to be used for further analysis. [18]

It should be noted that use of a bottom layer sample is extremely conservative for defining the compositional region (in terms of frit and heavy metal loading) in which complete dissolution is achieved. Bottom samples have a higher potential to have undissolved $\mathrm{PuO}_{2}$ due to actinide particle settling under static melt conditions. This provides a higher probability that the characterization tool (e.g., XRD, SEM, or optical microscopy) utilized will result in detection of undissolved $\mathrm{PuO}_{2}$. Thus, the use of bottom layer samples may restrict the "acceptable" frit composition region based on $\mathrm{PuO}_{2}$ and/or $\mathrm{UO}_{3}$ loading by effectively enhancing the detection limit of a given analytical instrument. Although not used, an alternative method of sample selection would be to grind the entire sample (10 - 15 grams of glass) and obtain a representative sample. For a given amount of undissolved $\mathrm{PuO}_{2}$ in the sample, detection probabilities would decrease due to the effect of diluting the undissolved $\mathrm{PuO}_{2}$ in the remaining sample. A "yes" / "no" decision was determined for the presence of undissolved material (in particular $\mathrm{PuO}_{2}$ ) using the conservative bottom samples.

SRTC has defined complete dissolution based on the detection limits of the XRD unit using standard operating parameters $\left(0.3 \mathrm{wt} \% \mathrm{PuO}_{2}\right)[18,19]$ and analysis by SEM/EDS which has a more sensitive detection limit relative to XRD [19]. All "as-fabricated" glasses were screened using $\mathrm{XRD}$ to determine if undissolved $\mathrm{PuO}_{2}$ was presence in the sample. If none were detected then the samples representing the melt bottom were evaluated by SEM/EDS.

Although the standard experimental procedures were documented[18], due to equipment and timing issues at the various laboratories, there were three obvious lab-to-lab differences in' the preparation and fabrication of the glasses: (1) crucibles used for melting, (2) analytical techniques for evaluating solubility and thermal stability, and (3) rate of cooling.

Crucibles

Both PNNL and ANL used Pt/Rh crucibles fabricated from a $\mathrm{Pt} / \mathrm{Rh}$ foil sheet. These crucibles (approximately 0.5 in $\times 0.5$ in $\times 2$ in) were fabricated by wrapping the $\mathrm{Pt} / \mathrm{Rh}$ foil around a square (cross-sectional), aluminum pre-form. The initial intent of utilizing the $\mathrm{Pt}$ foil crucible was to remove a monolithic sample that could be used in the thermal stability studies. That is, the glass could be fabricated (melted) in the foil crucible, cooled, and then the foil could be unwrapped exposing a glass monolith. During initial cold (surrogate) tests with these foils at SRTC, two questionable incidences occurred: (1) some of the Pt folds welded together making it difficult to remove or "unwrap" the foil exposing the monolith and (2) glass was observed in the folds of the Pt foil. Based on these observations, SRTC decided to use standard $35 \mathrm{ml}$, rounded bottom $\mathrm{Pt} / \mathrm{Rh}$ 


$$
\text { SRT-PUM-97-0017 }
$$

crucibles that had been used in previous testing with Pu-bearing LaBS glasses. Both PNNL and ANL used the square bottomed, Pt/Rh foil crucibles. The major concerns with the $\mathrm{Pt} / \mathrm{Rh}$ foil crucibles were "edge effects" and seepage (leakage) of glass into the folds. That is, it is possible that $\mathrm{PuO}_{2}$ that was initially isolated in the bottom corner (or edge) of the foil crucible could be restricted from the bulk glass melt during the static $1500^{\circ} \mathrm{C}$ heat treatment. If so, a sample from the bottom corner (or edge) of the foil crucible may misrepresent of the bulk melt or a non-restrictive melt condition. All melts were performed under "static" conditions which would limit the possibility of fully incorporating $\mathrm{PuO}_{2}$ isolated at the edges or corners. The seepage / leakage effect may lower the amount of glass which locally increases the $\mathrm{PuO}_{2}$ loading (assuming that $\mathrm{PuO}_{2}$ is settled on the bottom and does not travel with the low viscosity glass) leading to the identification of a non-homogeneous glass.

\section{Analytical Tool / Detection Limits}

The use of different analytical techniques to evaluate solubility and thermal stability provided another source of lab-to-lab variability. SRTC used both $X R D$ and SEM/EDS to evaluate glasses which were classified homogeneous by visual observation. Detection limits of the SRTC XRD results were approximately $0.3 \mathrm{wt} \% \mathrm{PuO}_{2}$ in the glass (bottom sample with potentially concentrated $\mathrm{PuO}_{2}$ ). SRTC also performed SEM/EDS analyses on representative samples to confirm both visual and XRD results. PNNL and ANL utilized optical microscopy to evaluate as fabricated and thermally treated glasses that were usually homogeneous. Use of optical microscopy provides an evaluation of the entire (bulk) sample (compared to only a surface analysis using SEM/EDS). ANNL also provided SEM analysis on select thermally heat treated glasses. Although, all three labs did provide visual observations of "as-fabricated" samples from the melt bottọm, the use of the different analytical techniques to determine the homogeneity of the visually homogeneous glasses provides an inconsistent set of data. The optical microscopy data lends itself to very subjective determinations on the quantity of undissolved material without the ability for qualitative identification. The latter is not a qualitative concern due to previous experience with undissolved $\mathrm{PuO}_{2}$ on the bottom of the melt.

\section{Cooling Rates}

The last known difference between the three laboratories was the cooling rate of the "as-fabricated" glasses. After the 4 hours residence time, both SRTC and PNNL placed the crucible in a water bath effectively water quenching the glass. ANL removed the crucible and allow it to air cool. Air cooling the sample will kinetically favor the formation of microstructure changes (if thermodynamically favorable). Based on previous experience, the only effect may be the observation of small $\mathrm{PuO}_{2}$ precipitates (0.5 micron size) in the glass matrix if cooling rates are dramatically different. This can easily be accessed by evaluation of the $\mathrm{PuO}_{2} /$ morphology. A rounded grain is usually indicative of undissolved $\mathrm{PuO}_{2}$, whereas, if devitrification occurs, the $\mathrm{PuO}_{2}$ is characterized by a dendritic or "star-like" morphology.

It should also be noted that these melts were performed under static conditions. Agitation (even infrequent, periodic stirring) of the melt is known to increase dissolution kinetics of 


$$
\text { SRT-PUM-97-0017 }
$$

$\mathrm{PuO}_{2}$ into the LaBS glass.[1,21] To minimize (if not eliminate) the effects of kinetics in the 90 test matrix glasses, a low-fired $\left(<450^{\circ} \mathrm{C}\right) \mathrm{PuO}_{2}$ was used by each site based on the observation of complete solubility of $11.4 \mathrm{wt} \% \mathrm{PuO}_{2}$ (low fired) in the "SRTC/PNNL" frit under similar melt conditions $\left(1500^{\circ} \mathrm{C}\right.$ for 4 hours).[1] However, the use of 90 different frit compositions may affect the kinetics and the assumption of "no kinetic effects" may not be valid. Therefore, undissolved $\mathrm{PuO}_{2}$ may be the result of kinetic differences between the base frit compositions and the use of static melt conditions. That is, given $\mathrm{PuO}_{2}$ was observed in a specific melt after 4 hours, with increased residence times complete dissolution may occur. Coupled with the differences in detection limits of the various analytical techniques utilized, the decision of whether a glass was "homogeneous" can become very subjective.

Devitrification

To assess the devitrification potential of the test matrix glasses, a specific thermal profile (heat up and cool down cycle) was used to simulate the thermal response of the Pu-bearing LaBS glass to the DWPF glass pour within the can-in-canister option. The temperature profile was calculated by Stein ${ }^{\dagger}$ using thermal codes and specific input parameters (can design, can location, HLW glass pour rates, nominal pour temperature, thermal properties of the LaBS glass, etc). The results indicated the can exposed to the maximum thermal load would be the upper, inner most portion of the top can. The thermal profile used for the devitrification tests is shown in Table VI.

Table VI. Thermal Profile Used to Evaluate Devitrification Potential of LaBS Glasses.

\begin{tabular}{cc}
\hline \hline Temperature $\left({ }^{\circ} \mathrm{C}\right)$ & Ramp Rate / Hold \\
\hline $650-915$ & over 1.25 hours (approx. $3.5^{\circ} \mathrm{C} / \mathrm{hr}$ ) \\
915 & hold for 1.25 hours \\
$915-650$ & over 5.5 hours (approx. $0.8^{\circ} \mathrm{C} / \mathrm{hr}$ ) \\
\hline
\end{tabular}

A representative sample from each "as-fabricated" test matrix glasses was individually subjected to this thermal profile using a Pt/Rh crucible. With few exceptions, glasses identified as homogeneous (complete solubility based on the detection limit of the analytical tool) were selected. After heat treatment, the sample was removed and visual, XRD, SEM/EDS, and/or optical microscopy evaluation was performed. As with the "asfabricated" samples, ANL and PNNL provided visual and optical microscopy analysis (with SEM analysis on select samples), while SRTC used XRD and SEM/EDS. Previous analysis of the "as-fabricated" samples provided a baseline for comparing microstructural changes due to the thermal cycle. Again, if microstructural changes occur, one must address the impact on the performance of the waste form. In fact, microstructural changes to a glass do not necessarily to lead to a reduction of product performance. The effect depends on the type and extent of crystallization and/or the type of microstructure (assuming amorphous phase separation) present.[16,17]

\footnotetext{
'Werner Stein, Lawrence Livermore National Laboratory, Thermal Fluids Group, "Modeling of Glass Temperature Distributions in a DWPF Canister", calculations using the ProCast Code to model flow of hot glass as it fills an initially empty canister and the temperature history during filling and subsequent cooling (1997).
} 


\section{SRT-PUM-97-0017}

\section{RESULTS/DISCUSSION}

\section{Solubility}

Tables VII - IX summarize the results of the solubility tests for SRTC, PNNL, and ANL respectively. The glass identification labels correspond to the composition of the glasses listed in Tables III - V. As a reference, the wt\% $\mathrm{PuO}_{2}$ and $\mathrm{PuO}_{2}+\mathrm{UO}_{3}$ loadings are also provided for each glass. As previously discussed, the use of various analytical techniques does present some difficulty for a "one-to-one" comparison in terms of defining complete dissolution. That is, the detection limit of the XRD unit used by SRTC is approximately $0.3 \mathrm{wt} \% \mathrm{PuO}_{2}$ (potentially concentrated bottom sample) versus the "unquantified" detection limit of the optical microscopy observations from both PNNL and ANL. The two primary questions that had to be addressed were: (1) can the detection limits of the various analytical tools be linked to provide a consistent set of data and (2) if not, can a subjective decision be made as to a "go / no go" (or "acceptable") label for each glass.

\section{SRTC Results}

Table VII summarizes the solubility results of the 30 SRTC LaBS glasses. Visual observations, XRD and SEM/EDS results are tabulated. Homogeneous glasses defined by complete dissolution (based on XRD results of a bottom sample) of $\mathrm{PuO}_{2}$ are identified by " $\mathrm{H}$ ". Glasses in which undissolved $\mathrm{PuO}_{2}$ was visually observed or detected in further analyses are labeled with "Pu". Based on visual observations, all but two glasses (L1-12 and L1-19) are homogeneous. These two glasses have $\mathrm{PuO}_{2}$ loadings of $15 \mathrm{wt} \%$ (the maximum evaluated) in which $\mathrm{PuO}_{2}$ was clearly evident on the bottom of the glass. Although not a very sensitive test, previous visual observations suggest that if no $\mathrm{PuO}_{2}$ is observed on the melt bottom that either complete dissolution occurred or that the percentage of undissolved $\mathrm{PuO}_{2}$ is relatively small. However, undissolved $\mathrm{PuO}_{2}$ is expected in some of the visually homogeneous glasses when evaluated by more sensitive techniques.

All SRTC "as-fabricated" glasses were evaluated by XRD. As expected, some of the homogeneous glasses as determined by visual observations do indeed have undissolved $\mathrm{PuO}_{2}$ above the $0.3 \mathrm{wt} \%$ detection limit. Those glasses are labeled with "Pu" in the XRD column of Table VII. Although $\mathrm{PuO}_{2}$ was identified in some of the glasses, quantitative XRD was not performed therefore no indication of the wt\% (or vol\%) can be described. Again, it should be pointed out that the sample evaluated was obtained from the bottom portion of the melt which increases the probability of concentrated $\mathrm{PuO}_{2}$ being the sample. Based on the intensity and shape of the $\mathrm{PuO}_{2}$ peaks observed in samples $\mathrm{L} 1-14,-15,-16$, and -27 , the percentage of $\mathrm{PuO}_{2}$ in that bottom sample is extremely small (just above detection limits). Quantitative XRD was used to determine the wt\% of undissolved $\mathrm{PuO}_{2}$ (using $\mathrm{Al}_{2} \mathrm{O}_{3}$ as an internal standard). The quantitative results indicate that $\mathrm{L} 1-14,-15$, -16 , and -27 have $0.1,0.6,1.1$, and $0.4 \mathrm{wt} \%$, respectively, undissolved $\mathrm{PuO}_{2}$ in the bottom samples.

The last column of Table VII lists the results of the SEM/EDS evaluation (again, the most sensitive test in terms of detection limits used by SRTC).[19] In order for a glass to receive an " $\mathrm{H}$ " label via SEM/EDS, no undissolved $\mathrm{PuO}_{2}$ could be observed. All glasses deemed homogeneous by XRD results were classified as homogeneous by SEM/EDS. The agreement between the two techniques provides a high degree of confidence that the L1 series glasses are well characterized in terms of $\mathrm{PuO}_{2}$ dissolution and are homogeneous consistent with the definitions. Defining "homogeneous" in this manner will limit or bound an "acceptable" processing region. If one were to take a representative sample of the entire 


$$
\text { SRT-PUM - 977-0017 }
$$

bulk glass, more glasses would be classified as "homogeneous" translating into an larger effective processing region. This is discussed in much greater detail in a later section.

One disadvantage of the SEM analysis is that it only provides a very sensitive analysis of a single surface (assuming a bulk piece that is mounted only once). To address this issue, a bottom sample of L1-21 (centroid) which was deemed homogeneous by all three methods (visual, XRD, and SEM/EDS) was crushed and reevaluated by SEM/EDS. No undissolved $\mathrm{PuO}_{2}$ was detected by SEM/EDS on any of the random surfaces evaluated (see Figure 2). Thus defining the SRTC centroid as homogeneous is well deserved and documented. 


$$
\text { SRT-PUM-97-0017 }
$$

Table VII. Solubility Results of SRTC Pu-Bearing LaBS Glasses (L1 series).

\begin{tabular}{lccccc}
\hline \hline Glass & $\mathrm{PuO}_{2}$ & $\mathrm{PuO}_{2}+\mathrm{UO}_{3}$ & Visual & $\mathrm{XRD}$ & $\begin{array}{c}\mathrm{SEM} / \mathrm{ED} \\
\mathrm{L}\end{array}$ \\
\hline $\mathrm{L} 1-01$ & 8.0 & 11.2 & $\mathrm{H}$ & $\mathrm{H}$ & $\mathrm{H}$ \\
$\mathrm{L} 1-02$ & 7.3 & 10.9 & $\mathrm{H}$ & $\mathrm{H}$ & $\mathrm{H}$ \\
$\mathrm{L} 1-03$ & 8.7 & 16.4 & $\mathrm{H}$ & $\mathrm{Pu}$ & - \\
$\mathrm{L} 1-04$ & 10.3 & 12.2 & $\mathrm{H}$ & $\mathrm{Pu}$ & - \\
$\mathrm{L} 1-05$ & 11.9 & 15.7 & $\mathrm{H}$ & $\mathrm{Pu}$ & - \\
\hline $\mathrm{L} 1-06$ & 10.3 & 12.2 & $\mathrm{H}$ & $\mathrm{Pu}$ & - \\
$\mathrm{L} 1-07$ & 2.4 & 6.3 & $\mathrm{H}$ & $\mathrm{H}$ & $\mathrm{H}$ \\
$\mathrm{L} 1-08$ & 2.4 & 10.1 & $\mathrm{H}$ & $\mathrm{H}$ & $\mathrm{H}$ \\
$\mathrm{L} 1-09$ & 2.4 & 6.3 & $\mathrm{H}$ & $\mathrm{H}$ & $\mathrm{H}$ \\
$\mathrm{L} 1-10$ & 2.4 & 2.4 & $\mathrm{H}$ & $\mathrm{H}$ & $\mathrm{H}$ \\
\hline $\mathrm{L} 1-11$ & 10.3 & 14.1 & $\mathrm{H}$ & $\mathrm{Pu}$ & - \\
$\mathrm{L} 1-12$ & 15.0 & 15.0 & $\mathrm{Pu}$ & $\mathrm{Pu}$ & - \\
$\mathrm{L} 1-13$ & 2.4 & 2.4 & $\mathrm{H}$ & $\mathrm{H}$ & $\mathrm{H}$ \\
$\mathrm{L} 1-14$ & 8.7 & 12.6 & $\mathrm{H}$ & $\mathrm{Pu}$ & - \\
$\mathrm{L} 1-15$ & 8.0 & 11.22 & $\mathrm{H}$ & $\mathrm{Pu}$ & - \\
\hline $\mathrm{L} 1-16$ & 8.7 & 12.6 & $\mathrm{H}$ & $\mathrm{Pu}$ & - \\
$\mathrm{L} 1-17$ & 2.4 & 2.4 & $\mathrm{H}$ & $\mathrm{H}$ & $\mathrm{H}$ \\
$\mathrm{L} 1-18$ & 2.4 & 10.1 & $\mathrm{H}$ & $\mathrm{H}$ & $\mathrm{H}$ \\
$\mathrm{L} 1-19$ & 15.0 & 15.0 & $\mathrm{Pu}$ & $\mathrm{Pu}$ & - \\
$\mathrm{L} 1-20$ & 15.0 & 22.7 & $\mathrm{H}$ & - & - \\
\hline $\mathrm{L} 1-21$ & 8.1 & 11.6 & $\mathrm{H}$ & $\mathrm{H}$ & $\mathrm{H}$ \\
$\mathrm{L} 1-22$ & 2.4 & 10.4 & $\mathrm{H}$ & $\mathrm{H}$ & $\mathrm{H}$ \\
$\mathrm{L} 1-23$ & 2.4 & 6.3 & $\mathrm{H}$ & $\mathrm{H}$ & $\mathrm{H}$ \\
$\mathrm{L} 1-24$ & 2.4 & 10.1 & $\mathrm{H}$ & $\mathrm{H}$ & $\mathrm{H}$ \\
$\mathrm{L} 1-25$ & 5.6 & 5.6 & $\mathrm{H}$ & $\mathrm{H}$ & $\mathrm{H}$ \\
\hline $\mathrm{L} 1-26$ & 5.6 & 7.5 & $\mathrm{H}$ & $\mathrm{H}$ & $\mathrm{H}$ \\
$\mathrm{L} 1-27^{*}$ & 11.9 & 15.7 & $\mathrm{H}$ & $\mathrm{Pu}$ & - \\
$\mathrm{L} 1-28$ & 8.7 & 10.6 & $\mathrm{H}$ & $\mathrm{H}$ & $\mathrm{Pu}$ \\
$\mathrm{L} 1-29$ & 10.3 & 16.1 & $\mathrm{H}$ & $\mathrm{H}$ & $\mathrm{H}$ \\
$\mathrm{L} 1-30$ & 15.0 & 15.0 & $\mathrm{H}$ & $\mathrm{Pu}$ & - \\
\hline & & & & & \\
\hline
\end{tabular}

$\mathrm{H}=$ Homogeneous

$\mathrm{Pu}=\mathrm{PuO}_{2}$ Detected

"-" = Not Analyzed

* Based on the intensity and shape of the $\mathrm{PuO}_{2}$ peaks observed in samples $\mathrm{L1}-14,-15,-16$, and -27 , the percentage of $\mathrm{PuO}_{2}$ in that bottom sample is extremely small (just above detection limits). Quantitative XRD was used to determine the wt\% of undissolved $\mathrm{PuO}_{2}$ (using $\mathrm{Al}_{2} \mathrm{O}_{3}$ as an internal standard). The results indicated $0.1,0.6,1.1$, and $0.4 \mathrm{wt} \%$, respectively, undissolved $\mathrm{PuO}_{2}$ in the bottom samples evaluated. 


$$
\text { SRT-PUM-97-0017 }
$$

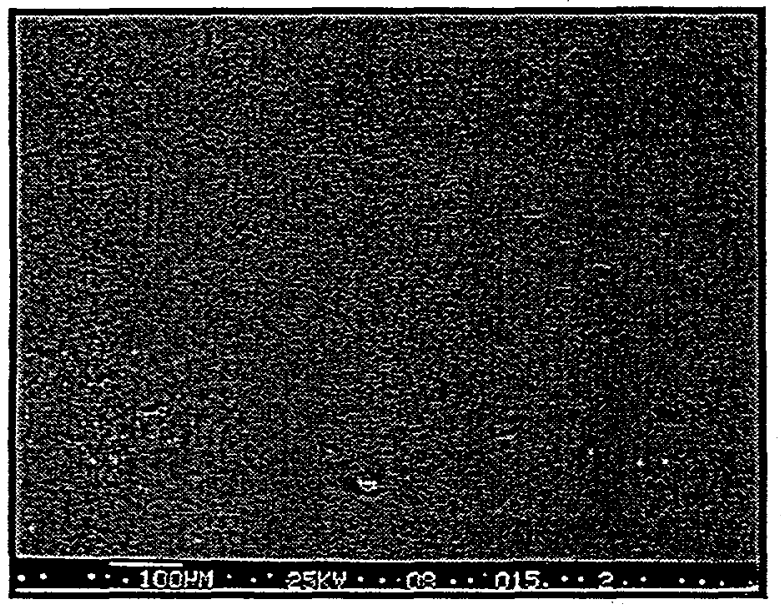

$100 X$
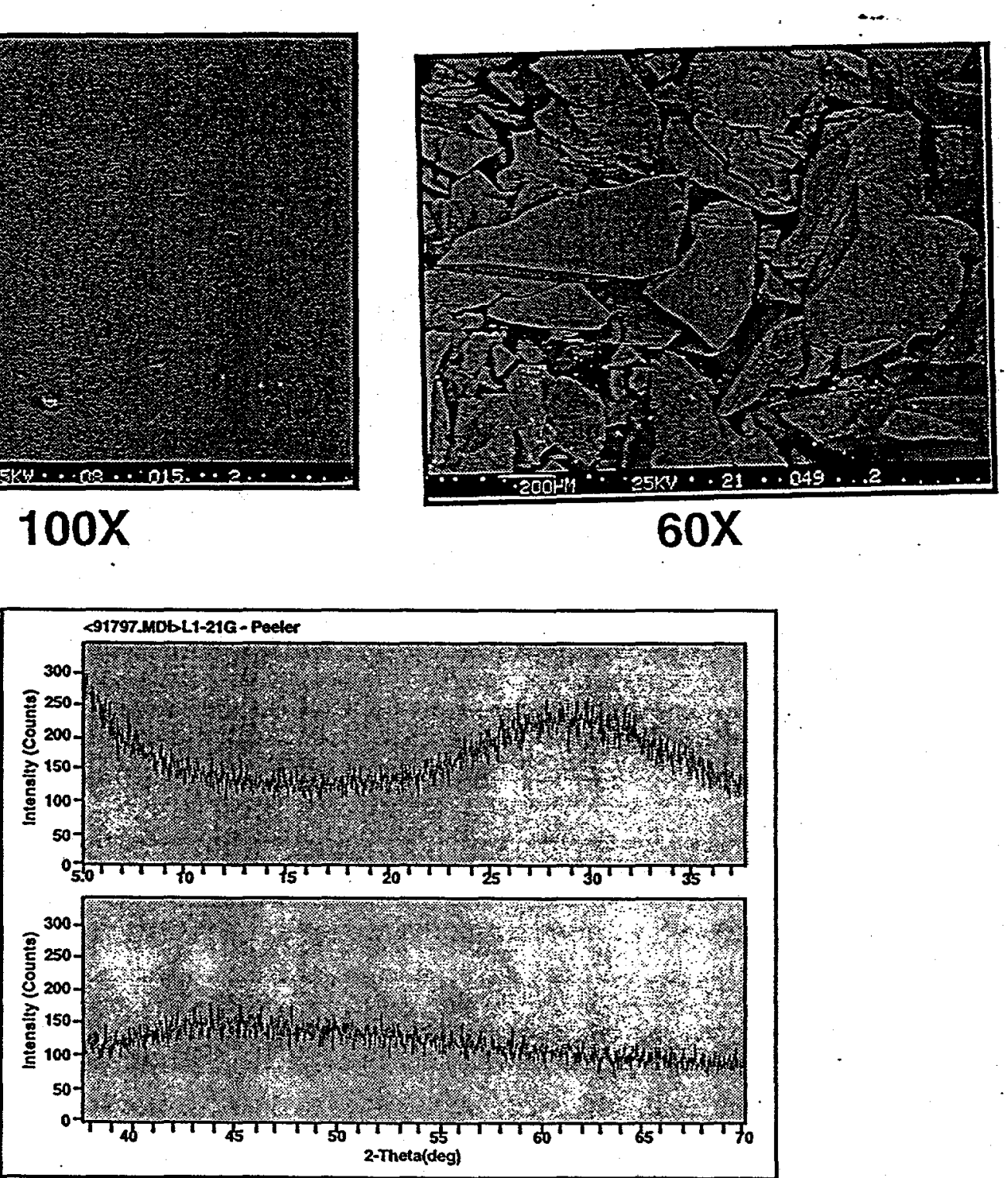

Figure 2. Results of SEM and XRD Analysis of L1-21 (SRTC's centroid). 


$$
\text { SRT-PUM - } 97-0017
$$

Figure 3 shows the 30 SRTC glasses in terms of a "frit $-\mathrm{PuO}_{2}+\mathrm{UO}_{3}$ - minor component" ternary. That is, the combined loading of $\mathrm{PuO}_{2}+\mathrm{UO}_{3}$ is located in the top corner of the ternary (ranging from $0 \mathrm{wt} \%$ up to $25 \mathrm{wt} \%$ ). The ranges of $\mathrm{PuO}_{2}+\mathrm{UO}_{3}$ in the $30 \mathrm{LaBS}$ glasses range from $2.4 \mathrm{wt} \%$ (minimum) up to $22.7 \mathrm{wt} \%$ (maximum). The "minor component" concentrations (at their maximum concentration) are indicated by the lower axis ranging from $0 \mathrm{wt} \%$ up to $25 \mathrm{wt} \%$ (although the upper limit of the minor components was $3.3 \mathrm{wt} \%$ ). The last ternary corner (lower right) represents the frit compositions as identified in Table III. Again, all 30 glasses are based on different frit compositions as well as different ratios of $\mathrm{Pu}, \mathrm{U}$, and "minor" components. Therefore, relating the effect of a specific LaBS frit composition to the solubility of the major variability components is lost within this particular figure.

Homogenous glass (as defined by both XRD and SEM/EDS analysis are represented by a dot ("•"). Glasses in which undissolved $\mathrm{PuO}_{2}$ was detected by either XRD or SEM/EDS are represented by a " $X$ ". Again, it should be pointed out that all of the glasses were fabricated under static melt and without mechanical stirring. The SRTC/PNNL frit is also shown on the "frit - $\mathrm{PuO}_{2}+\mathrm{UO}_{3}$ " binary labeled as " $\mathrm{B}$ ". This glass demonstrated complete dissolution of $13.4 \mathrm{wt} \% \mathrm{PuO}_{2}$ (no $\mathrm{UO}_{3}$ of minor components associated). [1] The homogenous (as defined in Figure 2) SRTC centroid (L1-21) is labeled as "C".

The results of the SRTC glasses show combined loadings of $\mathrm{PuO}_{2}+\mathrm{UO}_{3} \leq 10$ wt\% complete dissolution results independent of frit composition. That is, the LaBS system is flexible enough to allow for relatively major changes in the frit oxides and still produce homogeneous glasses with $\leq 10 \mathrm{wt} \% \mathrm{PuO}_{2}+\mathrm{UO}_{3}$. Four $\mathrm{L} 1$ series glasses containing This demonstrates the flexibility of the LaBS system to completely incorporate the maximum loading of the minor components at their maximum concentration. Higher loadings $(>10$ wt\% $\mathrm{PuO}_{2}+\mathrm{UO}_{3}$ ) can be achieved by optimization of the LaBS frit. Two glasses within this composition region are the "centroid" (L1-21) and the "SRTC/PNNL" frit. Table II compared the compositions of these two frits. The "SRTC/PNNL" frit demonstrated complete dissolution of at least $13.4 \mathrm{wt} \% \mathrm{PuO}_{2}$ (no $\mathrm{UO}_{3}$ or "minor" components present). Using a similar frit composition (exception $\mathrm{ZrO}_{2}$ almost double) the "centroid" glass (L121) demonstrated complete solubility of $8.1 \mathrm{wt} \% \mathrm{PuO}_{2}, 3.5 \mathrm{wt} \% \mathrm{UO}_{3}$, and $1.6 \mathrm{wt} \%$ "minor" components - a combined $\mathrm{PuO}_{2}+\mathrm{UO}_{3}$ loading of $11.6 \mathrm{wt} \%$.

If one considers the "borderline" glasses (L1-14, -15, -16, and -27) as homogeneous, Figure 4 shows the results of the SRTC glasses. This assumption is not unrealistic given the quantitative XRD results indicating that less than $0.1,0.6,1.1$, and $0.4 \mathrm{wt} \%$, respectively, undissolved $\mathrm{PuO}_{2}$ in the bottom samples and considering the static melt conditions.

Comparing Figures 3 and 4, more glasses within the $10-13.5 \mathrm{wt} \% \mathrm{PuO}_{2}+\mathrm{UO}_{3}$ combined loading region are classified as homogeneous which expands the potential processing region for this system. With the exception of L1-04 and L1-06 (due to overlapping compositions only one point shown above and to the left of the centroid), the LaBS system is again independent of frit composition in terms of "complete dissolution" under static melt conditions for combined loadings of $13.5 \mathrm{wt} \%$ or below.

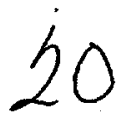


SRT-PUM-91-0017

\section{Solubility: 30 SRTC Glasses (L1 Series)}

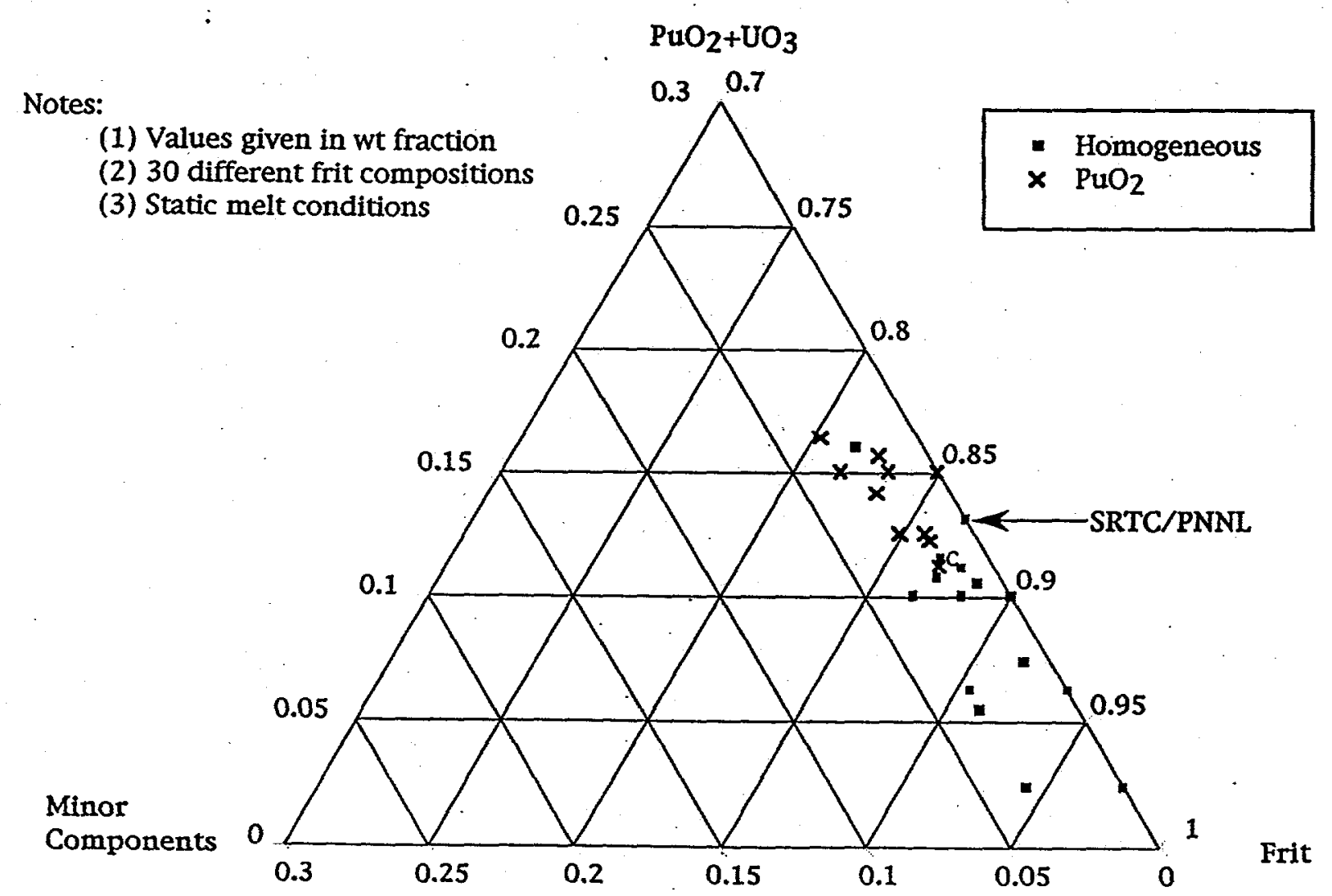

Figure 3. Solubility Results of the 30 SRTC Glasses as defined by XRD and SEM/EDS. 


\section{Solubility: 30 SRTC Glasses (L1 Series*)}

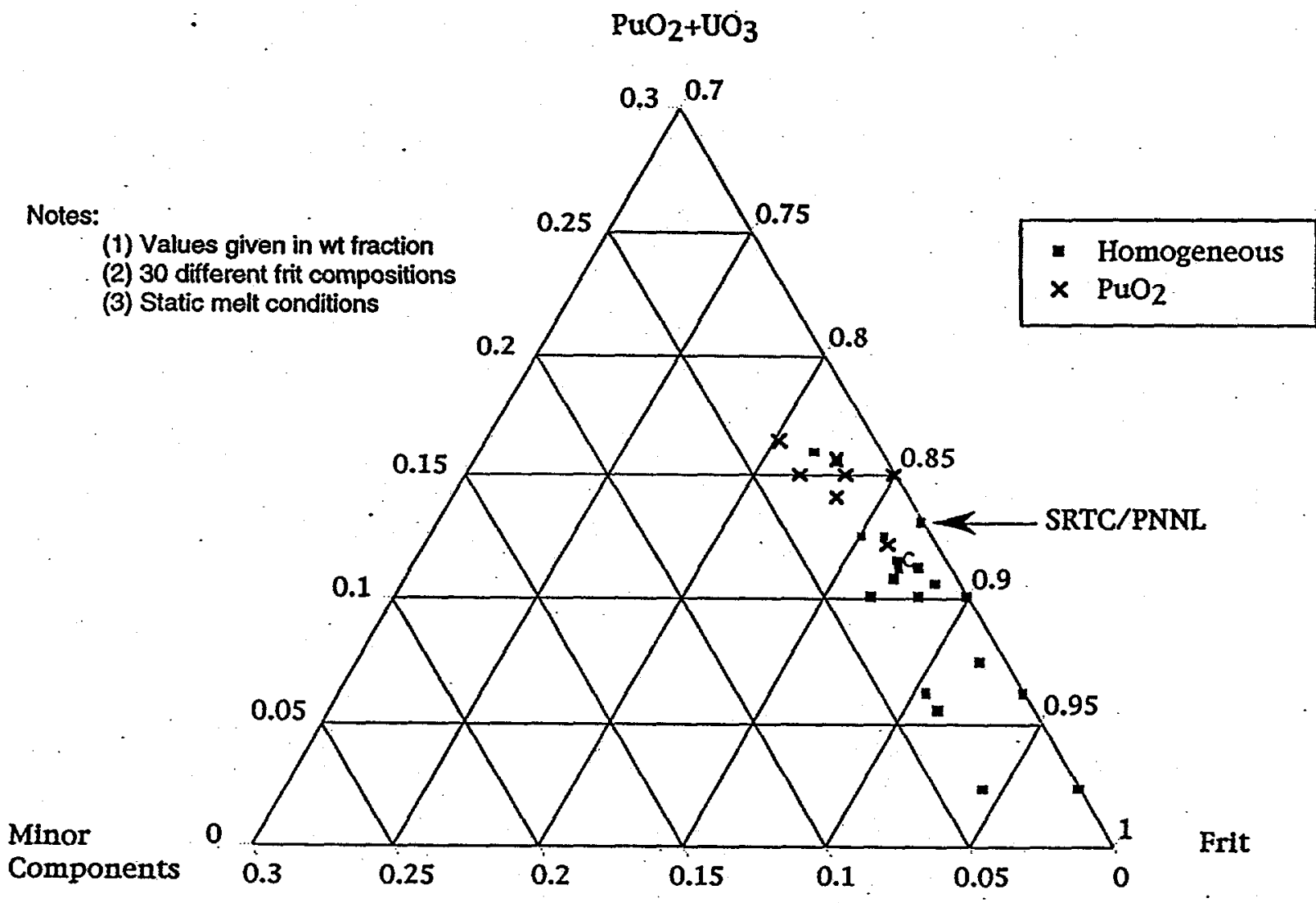

Figure 4. Solubility Results of the 30 SRTC Glasses as defined by XRD and SEM/EDS with the "Borderline" Glasses being Considered "Homogeneous".

*The "borderline" glasses (L1-14,-15,-16, and -27) contained $0.1,0.6,1.1$, and 0.4 wt $\%$, respectively, undissolved $\mathrm{PuO}_{2}$ as determined by quantitative XRD. 


\section{SRT-PUM - $97-0017$}

PNNL Results

Table VIII summarizes the solubility results of the 30 PNNL LaBS glasses. $\mathrm{PuO}_{2}$ and $\mathrm{PuO}_{2}+\mathrm{UO}_{3}$ loadings for each $\mathrm{L} 2$ series glass are given for reference. The unique frit compositions used for each glass are given in Table IV; these frits differ from those used by SRTC and ANL (exception being the centroid). PNNL provided a description of the visual observations for each "as-fabricated" glass. Homogeneous glasses defined by complete dissolution of $\mathrm{PuO}_{2}$ are identified by " $\mathrm{H}$ ". Glasses in which undissolved $\mathrm{PuO}_{2}$ was visually observed are labeled with "Pu". As with the 30 SRTC (L1 series) glasses, undissolved $\mathrm{PuO}_{2}$ was only observed in a few samples (primarily at the higher $\mathrm{PuO}_{2}$ loadings). Although not a very sensitive test, previous visual observations suggest that if no $\mathrm{PuO}_{2}$ is observed on the melt bottom that either complete dissolution occurred or that the percentage $\mathrm{PuO}_{2}$ is relatively small. However, undissolved $\mathrm{PuO}_{2}$ is expected in some of the visually homogeneous glasses when evaluated by more sensitive techniques.

As discussed earlier, due to time and equipment constraints, PNNL did not perform XRD and/or SEM/EDS analysis of the "as-fabricated" glasses. Instead, optical microscopy was used to provide insight into the homogeneity of each glass. As with the visual observations, PNNL provided a basic description of the optical microscopy results which are tabulated in the "optical" column of Table VIII. Homogeneous glasses are labeled with an " $\mathrm{H}$ " whereas glasses containing any degree of undissolved material are labeled as "Pu". It should be noted that although optical microscopy does not provide qualitative results, based on the morphology of the particles observed and previous experience, undissolved $\mathrm{PuO}_{2}$ can be identified based on particle morphology. The fact that the majority of the 30 PNNL glasses (20 out of the 30 ) contained some degree of undissolved material forces one to ask a series of questions: (1) could the lab-to-lab differences (crucibles, cooling rates, and/or analytical technique) cause this discrepancy, and (2) if so, which of the variations contributed to the discrepancy and to what extent?

Based on the documented descriptions of each sample, several L2 samples had only a limited amount of undissolved material dispersed throughout the matrix whereas other samples had large areas of agglomerated undissolved $\mathrm{PuO}_{2}$. Due to the fact that the optical microscopy tests are based on a "bulk" evaluation via transmitted light (compared to the surface analysis of the SEM/EDS or a "bulk" analysis based on the XRD sample), questions of how to quantify the percentage undissolved $\mathrm{PuO}_{2}$ in the $\mathrm{L} 2$ series became an issue. One must remember that these glasses were fabricated using Pt/Rh foil crucibles where possible edge effects may occur and under static melt conditions with the assumption that kinetics have been minimized (if not eliminated). Again, these differences and the use of a second "non-quantitative" analytical tool make it extremely difficult to compare the two sets of data (XRD versus optical microscopy) in terms of "complete dissolution".

Through discussions with both PNNL and ANL, the potential problems associated with the lab-to-lab variations resulting in the agreed approach to classify glasses as "acceptable" (identified by " $\mathrm{H}$ ") or "not acceptable" (identified by "Pu"). This determination was based solely on the individual laboratory that fabricated the specific glass. Glasses label " $H(M)$ " are borderline glasses as specified by PNNL. Although extremely subjective, this exercise was an attempt to "standardize" the PNNL optical data with the SRTC XRD data (having a 0.3 wt\% detection limit). One must remember, even though the standardization attempt is very subjective, that the samples being evaluated are from the melt bottom where concentration of the $\mathrm{PuO}_{2}$ is highly probable. If the entire sample were ground and a subsample were taken, the majority of the glasses (in particular the borderline glasses) would have a higher probability of being classified as homogeneous. The judgements being made are still very conservative in terms of classifying a glass as homogeneous particularly when fabricated under static conditions and the effect of kinetics are unknown 


$$
\text { SRT-PUM - 97-0017 }
$$

for each frit. Again, it should be pointed out that PNNL classified all the glasses as listed in Table VIII (no input from SRTC or ANL).

Figure 5 shows the 30 PNNL LaBS glasses plotted in the same base ternary using the "acceptable" optical microscopy data from Table VIII. As was observed in the SRTC glasses, at $\leq 10 \mathrm{wt} \% \mathrm{PuO}_{2}+\mathrm{UO}_{3}$ (combined loadings) the LaBS system is flexible enough to allow for relatively major changes in the frit oxide components and still produce homogeneous glasses. In other words, "complete dissolution" is independent of frit composition when $\leq 10 \mathrm{wt} \% \mathrm{PuO}_{2}+\mathrm{UO}_{3}$. Also, the four PNNL glasses containing the maximum loading of the minor components ( $3.3 \mathrm{wt} \%$ ) at $\mathrm{PuO}_{2}+\mathrm{UO}_{3}$ combined loadings of $\leq 10 \mathrm{wt} \%$ are homogeneous. This is consistent with the XRD and SEM/EDS based results of the SRTC ( $\mathrm{Ll}$ series) glasses. This demonstrates that complete dissolution of the minor components at their maximum concentrations and maximum loadings can be achieved.

Higher loadings $\left(>10 \mathrm{wt} \% \mathrm{PuO}_{2}+\mathrm{UO}_{3}\right.$ ) can be achieved by optimization of the $\mathrm{LaBS}$ frit. The PNNL "centroid" is classified as homogeneous which is consistent with SRTC's centroid (L1-21). Glasses above the $15 \mathrm{wt} \%$ combined heavy metal loading were classified "non-homogeneous" based on the bottom samples evaluated. 


$$
\text { SRT-PUM- } 97-0017
$$

Table VIII. Solubility Results of PNNL Pu-Bearing LaBS Glasses (L2 series).

\begin{tabular}{lccccc}
\hline \hline Glass & $\mathrm{PuO}_{2}$ & $\mathrm{PuO}_{2}+\mathrm{UO}_{3}$ & Visual & Optical & "Acceptable" \\
\hline $\mathrm{L} 2-01$ & 2.4 & 10.1 & $\mathrm{H}$ & $\mathrm{H}$ & $\mathrm{H}$ \\
$\mathrm{L} 2-02$ & 15.0 & 22.7 & $\mathrm{H}$ & $\mathrm{Pu}$ & $\mathrm{Pu}$ \\
$\mathrm{L} 2-03$ & 2.4 & 2.4 & $\mathrm{H}$ & $\mathrm{H}$ & $\mathrm{H}$ \\
$\mathrm{L} 2-04$ & 11.9 & 15.7 & $\mathrm{H}$ & $\mathrm{Pu}$ & $\mathrm{Pu}$ \\
$\mathrm{L} 2-05$ & 8.7 & 12.6 & $\mathrm{H}$ & $\mathrm{Pu}$ & $\mathrm{Pu}$ \\
\hline $\mathrm{L} 2-06$ & 7.9 & 11.2 & $\mathrm{H}$ & $\mathrm{H}$ & $\mathrm{H}$ \\
$\mathrm{L} 2-07$ & 8.1 & 11.6 & $\mathrm{H}$ & $\mathrm{Pu}$ & $\mathrm{H}(\mathrm{M})$ \\
$\mathrm{L} 2-08$ & 2.4 & 10.1 & $\mathrm{H}$ & $\mathrm{H}$ & $\mathrm{H}$ \\
$\mathrm{L} 2-09$ & 8.7 & 10.6 & $\mathrm{H}$ & $\mathrm{Pu}$ & $\mathrm{Pu}$ \\
$\mathrm{L} 2-10$ & 2.4 & 6.3 & $\mathrm{H}$ & $\mathrm{H}$ & $\mathrm{H}$ \\
\hline $\mathrm{L} 2-11$ & 5.6 & 11.3 & $\mathrm{H}$ & $\mathrm{Pu}$ & $\mathrm{H}(\mathrm{M})$ \\
$\mathrm{L} 2-12$ & 15.0 & 15.0 & $\mathrm{Pu}$ & $\mathrm{Pu}$ & $\mathrm{Pu}$ \\
$\mathrm{L} 2-13$ & 11.9 & 15.7 & $\mathrm{H}$ & $\mathrm{Pu}$ & $\mathrm{Pu}$ \\
$\mathrm{L} 2-14$ & 15.0 & 15.0 & $\mathrm{Pu}$ & $\mathrm{Pu}$ & $\mathrm{Pu}$ \\
$\mathrm{L} 2-15$ & 15.0 & 22.7 & $\mathrm{H}$ & $\mathrm{Pu}$ & $\mathrm{Pu}$ \\
\hline $\mathrm{L} 2-16$ & 8.0 & 10.5 & $\mathrm{H}$ & $\mathrm{Pu}$ & $\mathrm{Pu}$ \\
$\mathrm{L} 2-17$ & 8.7 & 10.6 & $\mathrm{H}$ & $\mathrm{Pu}$ & $\mathrm{Pu}$ \\
$\mathrm{L} 2-18$ & 8.7 & 8.7 & $\mathrm{Pu}$ & $\mathrm{Pu}$ & $\mathrm{H}(\mathrm{M})$ \\
$\mathrm{L} 2-19$ & 2.4 & 2.4 & $\mathrm{H}$ & $\mathrm{H}$ & $\mathrm{H}$ \\
$\mathrm{L} 2-20$ & 11.4 & 11.4 & $\mathrm{H}$ & $\mathrm{Pu}$ & $\mathrm{Pu}$ \\
\hline $\mathrm{L} 2-21$ & 7.1 & 11.0 & $\mathrm{H}$ & $\mathrm{Pu}$ & $\mathrm{H}(\mathrm{M})$ \\
$\mathrm{L} 2-22$ & 14.2 & 21.9 & $\mathrm{H}$ & $\mathrm{Pu}$ & $\mathrm{Pu}$ \\
$\mathrm{L} 2-23$ & 6.6 & 10.4 & $\mathrm{H}$ & $\mathrm{Pu}$ & $\mathrm{Pu}$ \\
$\mathrm{L} 2-24$ & 5.6 & 9.4 & $\mathrm{H}$ & $\mathrm{Pu}$ & $\mathrm{H}$ \\
$\mathrm{L} 2-25$ & 2.4 & 2.4 & $\mathrm{H}$ & $\mathrm{H}$ & $\mathrm{H}$ \\
\hline $\mathrm{L} 2-26$ & 5.6 & 13.2 & $\mathrm{H}$ & $\mathrm{Pu}$ & $\mathrm{H}(\mathrm{M})$ \\
$\mathrm{L} 2-27$ & 2.4 & 6.2 & $\mathrm{H}$ & $\mathrm{H}$ & $\mathrm{H}$ \\
$\mathrm{L} 2-28$ & 5.6 & 7.5 & $\mathrm{H}$ & $\mathrm{H}$ & $\mathrm{H}$ \\
$\mathrm{L} 2-29$ & 5.6 & 9.4 & $\mathrm{H}$ & $\mathrm{Pu}$ & $\mathrm{H}$ \\
$\mathrm{L} 2-30$ & 5.6 & 9.4 & $\mathrm{H}$ & $\mathrm{H}$ & $\mathrm{H}$ \\
\hline
\end{tabular}

$\mathrm{H}=$ Homogeneous

$\mathrm{H}(\mathrm{M})$ - "Borderline" Glasses

$\mathrm{Pu}=\mathrm{PuO}_{2}$ Detected 


\section{Solubility: 30 PNNL Glasses (L2 Series)}

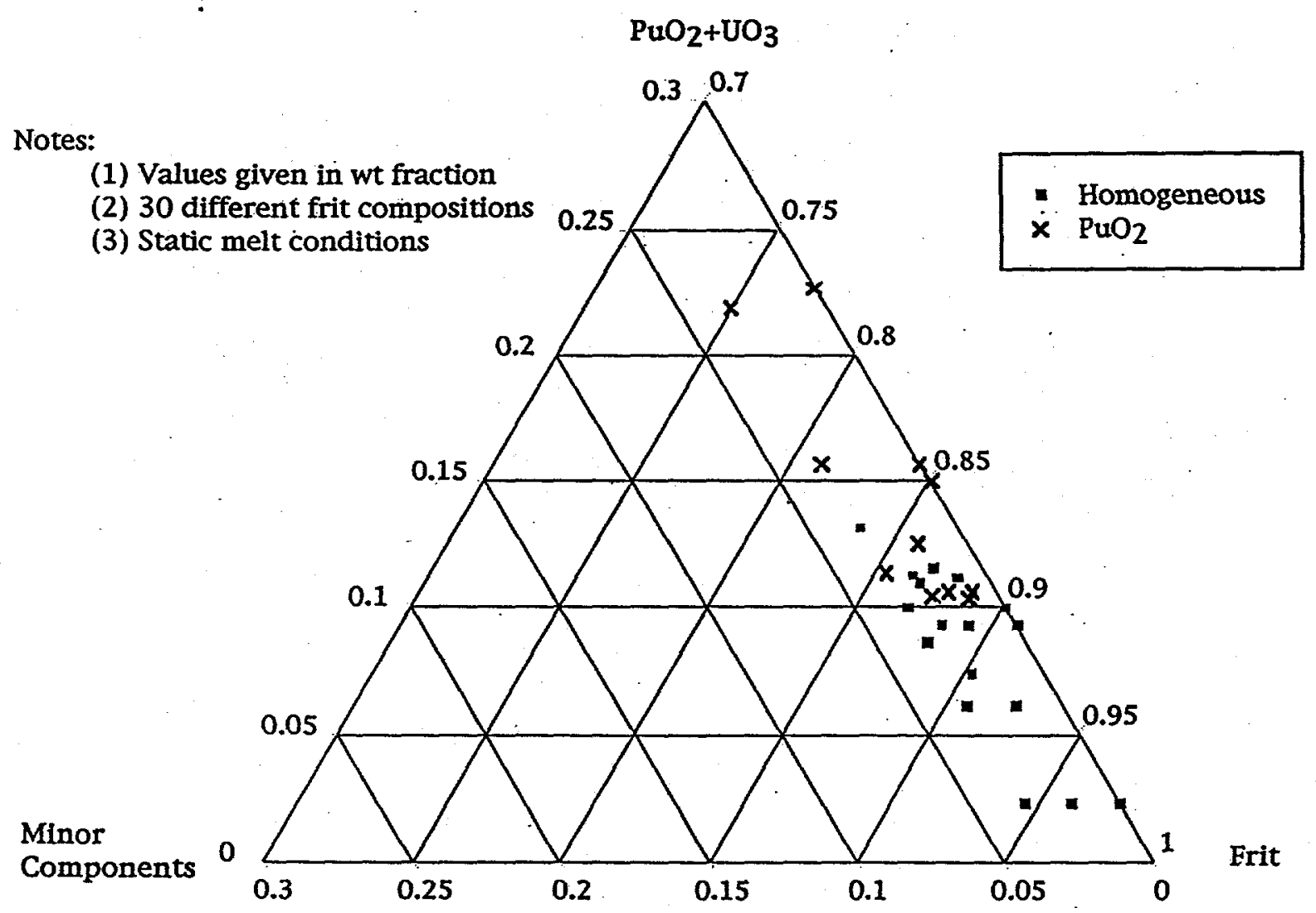

Figure 5. Solubility Results of the 30 PNNL Glasses.

(Glasses plotted based upon classification by PNNL as "acceptable") 


$$
\text { SRT - PUM - 97-0017 }
$$

ANL Results

Table IX summarizes the solubility results of the 30 ANL LaBS glasses (L3 series). $\mathrm{PuO}_{2}$ and $\mathrm{PuO}_{2}+\mathrm{UO}_{3}$ loadings for each glass are given for reference. The unique frit compositions for each glass are given in Table V - frit compositions for the L3 series differ from those used in either the L1 or L2 series with the exception of the centroid). ANL provided a visual description of each "as-fabricated" glass. Homogeneous glasses are identified by " $\mathrm{H}$ ". Glasses in which undissolved $\mathrm{PuO}_{2}$ was visually observed are labeled with "Pu". Glasses labeled by "." were not prepared based upon direction from SRTC. Those glasses were primarily high $\mathrm{PuO}_{2}+\mathrm{UO}_{3}$ loaded glasses (e.g., L2-21 targeted 22.2 wt\% combined loading) and given the time constraints higher priority melts replaced these glasses. As with the SRTC and PNNL glasses, a limited number of samples detected undissolved $\mathrm{PuO}_{2}$ based on visual observations. Although not a very sensitive test, previous visual observations suggest that if no $\mathrm{PuO}_{2}$ is observed on the melt bottom that either complete dissolution occurred or that the percentage $\mathrm{PuO}_{2}$ is relatively small. Undissolved $\mathrm{PuO}_{2}$ is expected in some of the visually homogeneous glasses when evaluated by more sensitive techniques as seen in the L1 and L 2 series.

As discussed earlier, due to time and equipment constraints, ANL did not perform XRD and/or SEM/EDS analysis of the "as-fabricated" glasses. Instead, optical microscopy was used to provide insight into the dissolution of $\mathrm{PuO}_{2}$ as was done by PNNL. However, ANL semi-quantified the degree of undissolved $\mathrm{PuO}_{2}$ by grading each bottom sample. Grades from 0 (no crystals observed) to 10 (abundance of undissolved $\mathrm{PuO}_{2}$ observed) were documented (see Table IX - "acceptable". column). For example, a grade of 0.3/10 (L3-04) is a sample were very little undissolved material was observed (a few crystals distributed throughout the entire sample).

Due to the fact that the optical microscopy tests evaluate the entire sample ("bulk") via transmitted light (compared to the surface analysis of the SEM/EDS and a "bulk" analysis based on the XRD sample), how does one link the graded optical microscopy results of a researcher to known detection limits of the XRD unit? The ANL glasses were fabricated using the Pt/Rh foil crucibles where possible edge effects may occur and under static melt conditions with the assumption that kinetics have been minimized (if not eliminated). Again, these differences and the use of a second "non-quantitative" analytical tool make it extremely difficult to compare the three sets of data in terms of "complete dissolution". Not only are there differences between the XRD and optical data, but even between the optical data provide by PNNL and ANL.

Through discussions with both PNNL and ANL, the potential problems associated with the lab-to-lab variations resulting in the agreed approach to classify glasses as "acceptable" (identified by " $\mathrm{H}$ ") or not (identified by "Pu"). ANL also classified their glasses as . "acceptable" and "unacceptable" without input from SRTC or PNNL. ANL determined that those glasses list in Table IX that have an optical rating or grade of 2 or less should be considered as "acceptable" and are labeled as " $\mathrm{H}$ ". Those with a grade of 3 or greater would be considered "unacceptable" and are labeled as "Pu". Although extremely subjective, this exercise was an attempt to "standardize" the ANL optical data with the SRTC XRD data (having a 0.3 wt\% detection limit) and the PNNL optical data. One must remember, even though the standardization attempt is subjective, that the samples being evaluated are from the bottom where concentration of the $\mathrm{PuO}_{2}$ is highly probable due to settling potential. If the entire sample were ground and a subsample were taken, the majority of the glasses (in particular those borderline glasses) would have a higher probability of being classified as homogeneous. The judgements being made are still very conservative in terms of classifying a glass as homogeneous particularly when fabricated under static conditions and unknown kinetics effects. It should be pointed out that ANL classified all the glasses as listed in Table IX (no input from SRTC or ANL). 


$$
\text { SRT-PUM- } 97-0017
$$

Figure 6 shows the 30 ANL LaBS glasses plotted in the same base ternary using the "acceptable" optical microscopy data. As was observed in both the SRTC and PNNL data, glasses in which the combined $\mathrm{PuO}_{2}+\mathrm{UO}_{3} \leq 10 \mathrm{wt} \%$, the LaBS system is flexible enough to allow for relatively major changes in the frit oxides and still produce homogeneous glasses. In other words, complete dissolution is independent of frit composition. There is one ANL glass that is an exception to this general rule: L3-17. This may be due to the subjective classification. Consistent with both the SRTC and PNNL observations, those glasses containing the maximum loading of minor components $(3.3 \mathrm{wt} \%)$ at $\mathrm{PuO}_{2}+\mathrm{UO}_{3} \leq$ $10 \mathrm{wt} \%$, are homogeneous. Complete dissolution is not limited by the minor components at their maximum concentration and the assumed maximum loading. Higher loadings $(>10$ wt\% $\mathrm{PuO}_{2}+\mathrm{UO}_{3}$ ) can be achieved by optimization of the LaBS frit. Two glasses in particular to point out: L3-09 and L3-06. L3-09 had a PuO 2 loading of 11.9 wt\% (with 1.7 wt\% minor components and no $\mathrm{UO}_{3}$ ). This glass was determined to be homogeneous by both visual observations and optical microscopy (without adjusting for detection limit differences). L3-06 contains $9.4 \mathrm{wt} \% \mathrm{PuO}_{2}$ and $2.5 \mathrm{wt} \% \mathrm{UO}_{3}$ (11.9 wt\% combined loading with $1.1 \mathrm{wt} \%$ minor components) and was visually homogeneous and given second lowest optical microscopy grade (suggesting very little undissolved material observed). Glasses near the $15 \mathrm{wt} \%$ combined heavy metal loading were classified "nonhomogeneous" based on the bottom samples evaluated.

It should be noted that L3-11 (the ANL centroid) was classified as "non-homogeneous" (optical rating of 5 out of 10). This results is inconsistent with the SRTC characterization of L1-21 (see Figure 2) and the classification by PNNL for L2-11. Again, questions of linking glasses defined as "acceptable" to the SRTC detection limits $(0.3 \mathrm{wt} \%)$ remain as well as the differences between the subjective ANL and PNNL classifications systems. 


$$
\text { SRT-PUM - } 97-0017
$$

Table IX. Solubility of ANL Pu-Bearing LaBS Glasses.

\begin{tabular}{lcccc}
\hline \hline Glass & $\mathrm{PuO}_{2}$ & $\mathrm{PuO}_{2}+\mathrm{UO}_{3}$ & Visual & "Acceptable" \\
\hline $\mathrm{L} 3-01$ & 8.7 & 14.0 & $\mathrm{H}$ & $\mathrm{Pu}(6 / 10)$ \\
$\mathrm{L} 3-02$ & 2.4 & 2.4 & $\mathrm{H}$ & $\mathrm{H}$ \\
$\mathrm{L} 3-03$ & 11.9 & 15.5 & $\mathrm{Pu}$ & $\mathrm{Pu}(4 / 10)$ \\
$\mathrm{L} 3-04$ & 6.6 & 8.9 & $\mathrm{H}$ & $\mathrm{H}(3 / 10)$ \\
$\mathrm{L} 3-05$ & 5.6 & 9.1 & bottom film & $\mathrm{H}(2 / 10 ; 0 / 10)$ \\
\hline $\mathrm{L} 3-06$ & 9.4 & 11.7 & $\mathrm{H}$ & $\mathrm{H}(.8 / 10)$ \\
$\mathrm{L} 3-07$ & 2.4 & 10.1 & $\mathrm{H}$ & $\mathrm{H}$ \\
$\mathrm{L} 3-08$ & 5.6 & 5.6 & bottom film & $\mathrm{H}$ \\
$\mathrm{L} 3-09$ & 11.9 & 11.9 & $\mathrm{H}$ & $\mathrm{H}$ \\
$\mathrm{L} 3-10$ & 2.4 & 2.4 & $\mathrm{H}$ & $*$ \\
\hline $\mathrm{L} 3-11$ & 8.1 & 11.3 & $\mathrm{H}$ & $\mathrm{Pu} \mathrm{(5/10)}$ \\
$\mathrm{L} 3-12$ & 8.7 & 14.1 & $\mathrm{H}$ & $\mathrm{Pu}(3 / 10)$ \\
$\mathrm{L} 3-13$ & 5.6 & 9.2 & bottom color & $\mathrm{H}(1 / 10)$ \\
$\mathrm{L} 3-14$ & 8.7 & 12.3 & $\mathrm{H}$ & $\mathrm{Pu}(3 / 10)$ \\
$\mathrm{L} 3-15$ & 2.4 & 2.4 & $\mathrm{H}$ & $\mathrm{H}$ \\
\hline $\mathrm{L} 3-16$ & 5.6 & 7.3 & $\mathrm{H}$ & $\mathrm{H}$ \\
$\mathrm{L} 3-17$ & 7.1 & 8.9 & $\mathrm{H}$ & $\mathrm{Pu}(4 / 10)$ \\
$\mathrm{L} 3-18$ & 15.0 & 15.0 & $\mathrm{H}$ & $\mathrm{Pu}(7 / 10)$ \\
$\mathrm{L} 3-19$ & 8.7 & 8.7 & $\mathrm{Pu}$ & $\mathrm{Pu}(0 / 10,4 / 10)$ \\
$\mathrm{L} 3-20$ & 10.7 & 10.7 & $\mathrm{H}$ & $\mathrm{Pu}(10 / 10)$ \\
\hline $\mathrm{L} 3-21$ & 15.0 & 22.2 & $\mathrm{NP}$ & $\mathrm{NP}$ \\
$\mathrm{L} 3-22$ & 11.9 & 15.5 & $\mathrm{NP}$ & $\mathrm{NP}$ \\
$\mathrm{L} 3-23$ & 2.4 & 6.0 & $\mathrm{H}$ & $\mathrm{H}(1.5 / 10)$ \\
$\mathrm{L} 3-24$ & 10.3 & 15.7 & $\mathrm{H}$ & $\mathrm{NP}$ \\
$\mathrm{L} 3-25$ & 6.6 & 10.1 & $\mathrm{H}$ & $\mathrm{Pu}(4.5 / 10)$ \\
\hline $\mathrm{L} 3-26$ & 15.0 & 21.9 & $\mathrm{NP}$ & $\mathrm{NP}$ \\
$\mathrm{L} 3-27$ & 2.4 & 9.7 & $\mathrm{H}$ & $\mathrm{H}$ \\
$\mathrm{L} 3-28$ & 2.4 & 9.7 & $\mathrm{H}$ & $\mathrm{H}(2 / 10)$ \\
$\mathrm{L} 3-29$ & 10.3 & 13.8 & $\mathrm{NP}$ & $\mathrm{NP}$ \\
$\mathrm{L} 3-30$ & 8.7 & 10.5 & $\mathrm{H}$ & $\mathrm{H}$ \\
\hline & & & &
\end{tabular}

$\mathrm{H}=$ Homogeneous

$\mathrm{Pu}=\mathrm{PuO}_{2}$ Detected

NP $=$ Not Prepared

$*=$ Not Analyzed 


\section{Solubility: 30 ANL Glasses (L3 Series)}

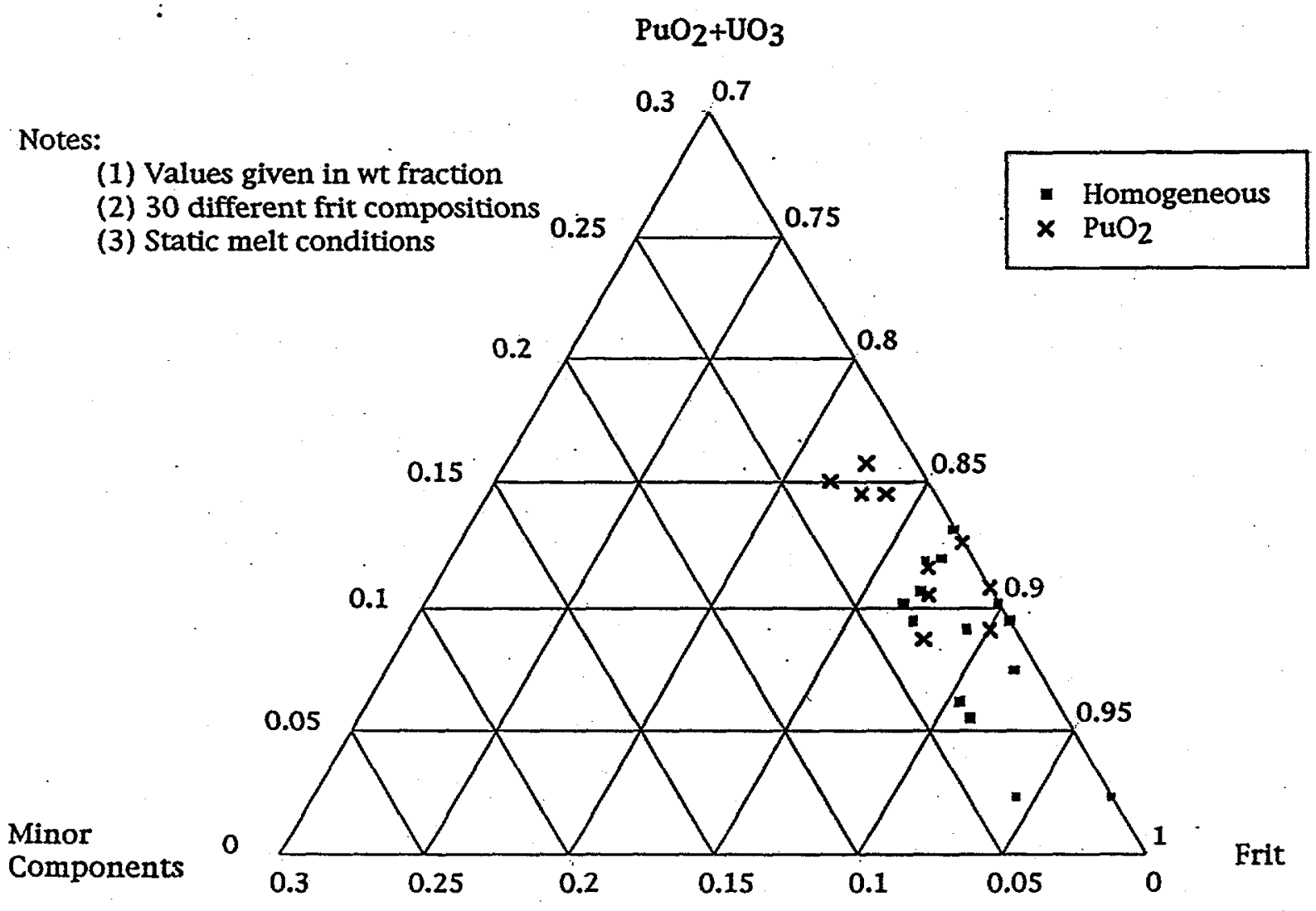

Figure 6. Solubility Results of the 30 ANL Glasses.

(Glasses plotted based upon classification by ANL as "acceptable") 


$$
\text { SRT-PUM - 97-0017 }
$$

Inter-Laboratory Solubility Data

Figure 7 shows the results of all 90 glasses as determined by SRTC (XRD) ${ }^{*}$, PNNL ("acceptable"), and ANL ("acceptable") data. Based on these results, the following solubility conclusions can be drawn:

- Complete dissolution of $\mathrm{PuO}_{2}$ and $\mathrm{UO}_{3}$ at combined loadings of $\leq 10 \mathrm{wt} \%$ have been demonstrated independent of the frit composition. This shows the flexibility of the LaBS system to allow for relatively major changes in the frit oxide components and still produce a homogeneous product. This was consistently shown by the three independent laboratories. Table X summarizes all the glasses meeting this criteria.

- Complete dissolution of $\mathrm{PuO}_{2}+\mathrm{UO}_{3}$ with combined loadings $>10 \mathrm{wt} \%$ have been demonstrated. Maximum $\mathrm{PuO}_{2}$ and $\mathrm{UO}_{3}$ loadings are achievable through frit optimization. Table XI summarizes all the glasses meeting this criteria.

- Complete dissolution of the minor components at their maximum concentrations and maximum loading ( $3.3 \mathrm{wt} \%$ in the glass) has been demonstrated up to 13.3 wt $\%$ combined loading of $\mathrm{PuO}_{2}$ and $\mathrm{UO}_{3}(\mathrm{~L} 2-26)$. At higher heavy metal loadings, the minor components do not limit the fabrication of a homogeneous system. The limiting factor is $\mathrm{PuO}_{2}$ and the definition of an acceptable product.

- $\mathrm{PuO}_{2}$ appears to be the limiting species for all 90 glasses. There was no indication of other species playing a major role in the definition of a homogeneous glass.

- Complete solubility of $\mathrm{UO}_{3}$ at the maximum loading $(7.7 \mathrm{wt} \%)$ has been demonstrated.

- The results are based on very conservative melt conditions and sample selection. Static melt conditions and analysis of a bottom sample are extremely conservative conditions from which to classify a melt as homogeneous or not. Even with these conservative conditions, a processing region can be defined which should expand if given the latitude to consider stirring and the bulk sample to define homogeneity.

SRTC glsses (L1-14, -15, -16, and -27) with quantitiative XRD results indicating undissolved $\mathrm{PuO}_{2}$ below $1.1 \mathrm{wt} \%$ are considered "acceptable" in this figure. 


\section{Solubility: All Test Matrix Glasses (SRTC, PNNL, and ANL)}

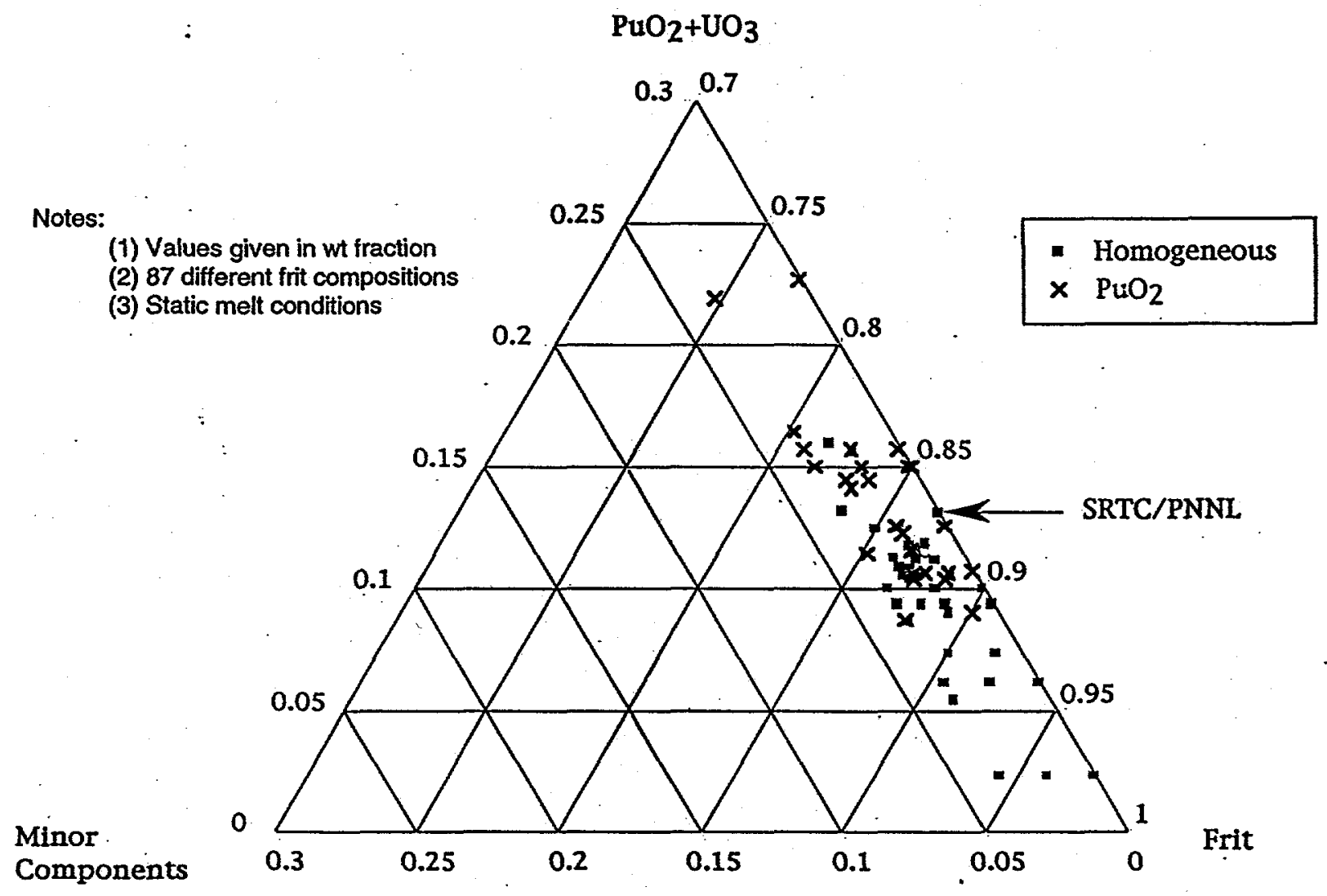

Figure 7. Results from the Inter-Laboratory Solubility Tests on the 90 Test Matrix Glasses 


$$
\text { SRT-PUM-97-0017 }
$$

Table X. Homogeneous Glasses up fabrication with $\leq 10 \mathrm{wt} \% \mathrm{PuO}_{2}$ and $\mathrm{UO}_{3}$ Loadings.

\begin{tabular}{|c|c|c|c|c|c|c|c|c|c|}
\hline $\begin{array}{l}\text { Glass } \\
\text { ID } \\
\text { L1-07 } \\
\text { L1-09 } \\
\text { L1-10 } \\
\text { L1-13 } \\
\text { L1-17 } \\
\text { L1-18 } \\
\text { L1-23 } \\
\text { L } 1-25 \\
\text { L } 1-26\end{array}$ & $\begin{array}{l}\mathrm{PuO}_{2} \\
0.024 \\
0.024 \\
0.024 \\
0.024 \\
0.024 \\
0.024 \\
0.024 \\
0.056 \\
0.056\end{array}$ & $\begin{array}{l}\mathrm{UO}_{3} \\
0.039 \\
0.039 \\
0.000 \\
0.000 \\
0.000 \\
0.077 \\
0.039 \\
0.000 \\
0.019\end{array}$ & $\begin{array}{l}\text { Minor } \\
\text { Comp. } \\
0.000 \\
0.000 \\
0.000 \\
0.000 \\
0.033 \\
0.000 \\
0.033 \\
0.033 \\
0.008\end{array}$ & $\begin{array}{l}\mathrm{SiO}_{2} \\
0.176 \\
0.249 \\
0.321 \\
0.176 \\
0.176 \\
0.176 \\
0.321 \\
0.321 \\
0.285\end{array}$ & $\begin{array}{l}\mathrm{B}_{2} \mathrm{O}_{3} \\
0.129 \\
0.100 \\
0.071 \\
0.129 \\
0.071 \\
0.129 \\
0.071 \\
0.071 \\
0.086\end{array}$ & $\begin{array}{l}\mathrm{Al}_{2} \mathrm{O}_{3} \\
0.192 \\
0.253 \\
0.253 \\
0.130 \\
0.130 \\
0.253 \\
0.185 \\
0.188 \\
0.175 \\
\end{array}$ & $\begin{array}{l}\text { SrO } \\
0.015 \\
0.015 \\
0.029 \\
0.029 \\
0.015 \\
0.015 \\
0.015 \\
0.029 \\
0.026 \\
\end{array}$ & $\begin{array}{l}\mathrm{ZrO}_{2} \\
0.008 \\
0.021 \\
0.008 \\
0.034 \\
0.008 \\
0.008 \\
0.034 \\
0.021 \\
0.022\end{array}$ & $\begin{array}{l}\text { Rare } \\
\text { Earths } \\
0.418 \\
0.300 \\
0.294 \\
0.478 \\
0.543 \\
0.318 \\
0.279 \\
0.281 \\
0.325 \\
\end{array}$ \\
\hline $\begin{array}{l}L 2-03 \\
L 2-10 \\
L 2-18 \\
L 2-19 \\
L 2-24 \\
L 2-25 \\
L 2-27 \\
L 2-28 \\
L 2-29 \\
L 2-30\end{array}$ & $\begin{array}{l}0.024 \\
0.024 \\
0.087 \\
0.024 \\
0.056 \\
0.024 \\
0.024 \\
0.056 \\
0.056 \\
0.056\end{array}$ & $\begin{array}{l}0.000 \\
0.039 \\
0.000 \\
0.000 \\
0.039 \\
0.000 \\
0.039 \\
0.019 \\
0.039 \\
0.039\end{array}$ & $\begin{array}{l}0.033 \\
0.033 \\
0.033 \\
0.017 \\
0.025 \\
0.000 \\
0.017 \\
0.025 \\
0.016 \\
0.000\end{array}$ & $\begin{array}{l}0.176 \\
0.176 \\
0.321 \\
0.321 \\
0.277 \\
0.176 \\
0.176 \\
0.248 \\
0.248 \\
0.321\end{array}$ & $\begin{array}{l}0.071 \\
0.129 \\
0.129 \\
0.100 \\
0.086 \\
0.129 \\
0.129 \\
0.086 \\
0.100 \\
0.071\end{array}$ & $\begin{array}{l}0.130 \\
0.192 \\
0.130 \\
0.192 \\
0.161 \\
0.130 \\
0.253 \\
0.209 \\
0.172 \\
0.241\end{array}$ & $\begin{array}{l}0.029 \\
0.022 \\
0.029 \\
0.022 \\
0.019 \\
0.015 \\
0.029 \\
0.019 \\
0.026 \\
0.015\end{array}$ & $\begin{array}{l}0.008 \\
0.008 \\
0.015 \\
0.021 \\
0.015 \\
0.034 \\
0.008 \\
0.015 \\
0.015 \\
0.008\end{array}$ & $\begin{array}{l}0.529 \\
0.378 \\
0.257 \\
0.304 \\
0.325 \\
0.492 \\
0.326 \\
0.325 \\
0.329 \\
0.250\end{array}$ \\
\hline $\begin{array}{l}\text { L3-02 } \\
\text { L3-04 } \\
\text { L3-05 } \\
\text { L3-08 } \\
\text { L3-10 } \\
\text { L3-13 } \\
\text { L3-15 } \\
\text { L3-16 } \\
\text { L3-23 } \\
\text { L3-27 } \\
\text { L3-28 }\end{array}$ & $\begin{array}{l}0.024 \\
0.066 \\
0.056 \\
0.056 \\
0.024 \\
0.056 \\
0.024 \\
0.056 \\
0.024 \\
0.024 \\
0.024\end{array}$ & $\begin{array}{l}0.000 \\
0.025 \\
0.039 \\
0.000 \\
0.000 \\
0.039 \\
0.000 \\
0.019 \\
0.039 \\
0.077 \\
0.077\end{array}$ & $\begin{array}{l}0.033 \\
0.017 \\
0.000 \\
0.033 \\
0.000 \\
0.033 \\
0.000 \\
0.008 \\
0.033 \\
0.033 \\
0.000\end{array}$ & $\begin{array}{l}0.176 \\
0.224 \\
0.249 \\
0.321 \\
0.176 \\
0.321 \\
0.176 \\
0.285 \\
0.321 \\
0.321 \\
0.176\end{array}$ & $\begin{array}{l}0.071 \\
0.110 \\
0.100 \\
0.100 \\
0.071 \\
0.071 \\
0.129 \\
0.114 \\
0.100 \\
0.071 \\
0.071\end{array}$ & $\begin{array}{l}0.130 \\
0.172 \\
0.192 \\
0.174 \\
0.253 \\
0.130 \\
0.253 \\
0.161 \\
0.130 \\
0.201 \\
0.130\end{array}$ & $\begin{array}{l}0.015 \\
0.020 \\
0.029 \\
0.015 \\
0.015 \\
0.015 \\
0.015 \\
0.019 \\
0.029 \\
0.015 \\
0.029\end{array}$ & $\begin{array}{l}0.034 \\
0.017 \\
0.021 \\
0.008 \\
0.034 \\
0.021 \\
0.008 \\
0.015 \\
0.034 \\
0.008 \\
0.008\end{array}$ & $\begin{array}{l}0.517 \\
0.350 \\
0.316 \\
0.294 \\
0.427 \\
0.315 \\
0.395 \\
0.325 \\
0.291 \\
0.250 \\
0.485\end{array}$ \\
\hline
\end{tabular}

Table X. Homogeneous Glasses upon fabrication with $>10 \mathrm{wt} \% \mathrm{PuO}_{2}$ and $\mathrm{UO}_{3}$ Loadings.

\begin{tabular}{|c|c|c|c|c|c|c|c|c|c|}
\hline $\begin{array}{l}\text { Glass } \\
\text { ID }\end{array}$ & $\mathrm{PuO}_{2}$ & $\mathrm{UO}_{3}$ & $\begin{array}{l}\text { Minor } \\
\text { Comp. }\end{array}$ & $\mathrm{SiO}_{2}$ & $\mathrm{~B}_{2} \mathrm{O}_{3}$ & $\mathrm{Al}_{2} \mathrm{O}_{3}$ & $\mathrm{SrO}$ & $\mathrm{ZrO}_{2}$ & $\begin{array}{l}\text { Rare } \\
\text { Earths }\end{array}$ \\
\hline $\begin{array}{l}\text { L1-01 } \\
\text { L1-02 } \\
\text { L1-08 } \\
\text { L1-21 } \\
\text { L1-22 } \\
\text { L1-24 } \\
\text { L1-29 }\end{array}$ & $\begin{array}{l}0.080 \\
0.073 \\
0.024 \\
0.081 \\
0.024 \\
0.024 \\
0.103\end{array}$ & $\begin{array}{l}0.033 \\
0.036 \\
0.077 \\
0.035 \\
0.077 \\
0.077 \\
0.058\end{array}$ & $\begin{array}{l}0.011 \\
0.022 \\
0.000 \\
0.016 \\
0.017 \\
0.033 \\
0.023\end{array}$ & $\begin{array}{l}0.227 \\
0.224 \\
0.321 \\
0.241 \\
0.249 \\
0.320 \\
0.212\end{array}$ & $\begin{array}{l}0.092 \\
0.090 \\
0.071 \\
0.098 \\
0.100 \\
0.129 \\
0.086\end{array}$ & $\begin{array}{l}0.171 \\
0.171 \\
0.130 \\
0.185 \\
0.192 \\
0.130 \\
0.161\end{array}$ & $\begin{array}{l}0.020 \\
0.020 \\
0.015 \\
0.022 \\
0.029 \\
0.029 \\
0.019\end{array}$ & $\begin{array}{l}0.017 \\
0.017 \\
0.034 \\
0.021 \\
0.034 \\
0.008 \\
0.015\end{array}$ & $\begin{array}{l}0.350 \\
0.349 \\
0.328 \\
0.301 \\
0.280 \\
0.250 \\
0.325\end{array}$ \\
\hline $\begin{array}{l}\text { L2-01 } \\
\text { L2-06 } \\
\text { L2-07 } \\
\text { L2-08 } \\
\text { L2-11 } \\
\text { L2-21 }\end{array}$ & $\begin{array}{l}0.024 \\
0.080 \\
0.081 \\
0.024 \\
0.056 \\
0.071\end{array}$ & $\begin{array}{l}0.077 \\
0.033 \\
0.035 \\
0.077 \\
0.058 \\
0.039\end{array}$ & $\begin{array}{l}0.033 \\
0.011 \\
0.016 \\
0.000 \\
0.025 \\
0.025\end{array}$ & $\begin{array}{l}0.243 \\
0.224 \\
0.241 \\
0.321 \\
0.258 \\
0.261\end{array}$ & $\begin{array}{l}0.071 \\
0.097 \\
0.099 \\
0.129 \\
0.086 \\
0.086\end{array}$ & $\begin{array}{l}0.253 \\
0.171 \\
0.185 \\
0.130 \\
0.161 \\
0.161\end{array}$ & $\begin{array}{l}0.015 \\
0.020 \\
0.022 \\
0.029 \\
0.019 \\
0.019\end{array}$ & $\begin{array}{l}0.034 \\
0.017 \\
0.021 \\
0.008 \\
0.015 \\
0.015\end{array}$ & $\begin{array}{l}0.250 \\
0.349 \\
0.301 \\
0.282 \\
0.325 \\
0.325\end{array}$ \\
\hline $\begin{array}{l}\text { L2-26 } \\
\text { L3-06 } \\
\text { L3-07 } \\
\text { L3-09 } \\
\text { L3-30 }\end{array}$ & $\begin{array}{l}0.056 \\
0.094 \\
0.024 \\
0.119 \\
0.087\end{array}$ & $\begin{array}{l}0.077 \\
0.025 \\
0.077 \\
0.000 \\
0.020\end{array}$ & $\begin{array}{l}0.033 \\
0.011 \\
0.033 \\
0.017 \\
0.025\end{array}$ & $\begin{array}{l}0.249 \\
0.224 \\
0.176 \\
0.249 \\
0.265\end{array}$ & $\begin{array}{l}0.100 \\
0.090 \\
0.129 \\
0.129 \\
0.086\end{array}$ & $\begin{array}{l}0.130 \\
0.171 \\
0.248 \\
0.130 \\
0.161\end{array}$ & $\begin{array}{l}0.029 \\
0.020 \\
0.029 \\
0.020 \\
0.019\end{array}$ & $\begin{array}{l}0.021 \\
0.017 \\
0.034 \\
0.008 \\
0.015\end{array}$ & $\begin{array}{l}0.306 \\
0.349 \\
0.250 \\
0.321 \\
0.325\end{array}$ \\
\hline
\end{tabular}




\section{Devitrification}

$$
\text { SRT-PUM-97-0017 }
$$

Tables XI - XIII summarize the homogeneity results for the thermally heat treated glasses from SRTC, PNNL and ANL laboratories. SRTC evaluated "as-fabricated" glasses defined as homogeneous by XRD and SEM (as listed in Table VII). SEM/EDS analysis was performed to evaluate the microstructure after heat treatment.with the results listed in Table XI. ANL heat treated "as-fabricated" glasses defined as homogeneous or "acceptable" (2/10 or less grade) and PNNL heat treated glasses defined as homogeneous upon fabrication with $\mathrm{PuO}_{2}+\mathrm{UO}_{3}$ loadings ranging from $6 \mathrm{wt} \%$ up to $12 \mathrm{wt} \%$. Both the ANL and PNNL heat treated glasses were evaluated via optical microscopy. ANL examined select glasses via SEM. The results for PNNL and ANL are tabulated in Tables $\mathrm{XII}$ and XII respectively.

Figure 8 shows the results from the three laboratories. Initial indications suggests that devitrification potential is linked not only to $\mathrm{PuO}_{2}$ loading but also to frit composition. For example, $\mathrm{L} 1-07$ and $\mathrm{L} 1-26$ have $\mathrm{PuO}_{2}+\mathrm{UO}_{3}$ combined loadings $<10 \mathrm{wt} \%$ which devitrify $\mathrm{PuO}_{2}$ upon heat treatment. Several other glasses with combined loadings of $<10 \mathrm{wt} \%$ are homogeneous after heat treatment. Again, all test matrix glasses had different frit compositions (exception being the centroid).

Table XIV summarizes those homogeneous glasses (after heat treatment) with combined $\mathrm{PuO}_{2}+\mathrm{UO}_{3}$ loadings of $>10 \mathrm{wt} \%$. In general, these glasses all have relatively high $\mathrm{RE}_{2} \mathrm{O}_{3}$ loadings as compared to the centroid ( $30 \mathrm{wt} \% \mathrm{RE}_{2} \mathrm{O}_{3}$ ). Higher $\mathrm{RE}_{2} \mathrm{O}_{3}$ loadings may decrease the potential for phase instability but are also known to limit actinide solubility.[15] Although $\mathrm{PuO}_{2}$ does devitrify, it has been observed that both $\mathrm{Gd}_{2} \mathrm{O}_{3}$ (and other rare earth that are effective neutron absorbers) and $\mathrm{ZrO}_{2}$ also partition with the $\mathrm{PuO}_{2} \cdot[22]$

\section{Effect on Performance}

Although microstructural changes occur in a glass matrix, the effects on performance depend upon the type and extent of devitrification and/or microstructure type developed if amorphous phase separation. The thermal instability produces devitrification of $\mathrm{PuO}_{2}$ crystals (with rare earths including $\mathrm{Gd}_{2} \mathrm{O}_{3}$ and $\mathrm{ZrO}_{2}$ observed to partition in the crystal as well). These crystals are approximately 0.5 micron in size. The resulting size depends upon both the time and temperature of heat treatment. Meaker [22] has observed up to 10 micron sized $\mathrm{PuO}_{2}$ (with $\mathrm{Gd}$ and $\mathrm{Zr}$ ) at higher temperatures and times.

To evaluate the effect on performance, a LaBS glass (approximating the SRTCIPNNL frit with $\left.9.1 \mathrm{wt} \% \mathrm{PuO}_{2}\right)$ was heat treated resulting in devitrification. Samples from the "asfabricated" (homogenous) glass and the heat treated sample $\left(\mathrm{PuO}_{2}\right.$ devitrified) were subjected to the Product Consistency Test (PCT) as a measure of durability. Table XV shows the normalized elemental release rates for $\mathrm{Si}, \mathrm{B}, \mathrm{Nd}$, and $\mathrm{Pu}$ for the two samples. There is no significant difference in the performance of the homogeneous, as-fabricated sample to the heat treated, $\mathrm{PuO}_{2}$ devitrified sample. In fact, one could concluded that the release rates of $\mathrm{Pu}$ decrease by as much as a factor of three in the devitrified glass.

Table XV. Performance Comparison of a Homogeneous and a LaBS Glass Containing $\mathrm{PuO}_{2}$ Crystals (from devitrification).

\begin{tabular}{lllll}
\hline \hline Sample & NL $[\mathrm{Si}]$ & NL $[\mathrm{B}]$ & NL $[\mathrm{Nd}]$ & NL $[\mathrm{Pu}]$ \\
\hline Homogeneous & 0.019 & 0.026 & $<2.2 \mathrm{E}-04$ & 0.015 \\
$\mathrm{PuO}_{2}$ Present & 0.020 & 0.029 & $<2.2 \mathrm{E}-04$ & 0.003 \\
\hline
\end{tabular}




$$
\text { SRT-PUM-97-0017 }
$$

Table XI. Devitrification Data of SRTC Pu-Bearing LaBS Glasses.

\begin{tabular}{lcccc}
\hline \hline Glass & $\mathrm{PuO}_{2}$ & $\mathrm{PuO}_{2}+\mathrm{UO}_{3}$ & Visual & SEM/EDS \\
\hline $\mathrm{L} 1-01$ & 8.0 & 11.2 & $\mathrm{H}$ & $\mathrm{H}$ \\
$\mathrm{L} 1-02$ & 7.3 & 10.9 & $\mathrm{H}$ & $\mathrm{H}$ \\
$\mathrm{L} 1-07$ & 2.4 & 6.3 & $\mathrm{H}$ & $\mathrm{Pu}$ \\
$\mathrm{L} 1-08$ & 2.4 & 10.1 & $\mathrm{H}$ & $\mathrm{H}$ \\
\hline $\mathrm{L} 1-09$ & 2.4 & 6.3 & $\mathrm{H}$ & $\mathrm{H}$ \\
$\mathrm{L} 1-10$ & 2.4 & 2.4 & $\mathrm{H}$ & $\mathrm{H}$ \\
$\mathrm{L} 1-13$ & 2.4 & 2.4 & $\mathrm{H}$ & $\mathrm{H}$ \\
$\mathrm{L} 1-17$ & 2.4 & 2.4 & $\mathrm{H}$ & $\mathrm{H}$ \\
\hline $\mathrm{L} 1-18$ & 2.4 & 10.1 & $\mathrm{H}$ & $\mathrm{Pu}$ \\
$\mathrm{L} 1-21$ & 8.1 & 11.6 & $\mathrm{H}$ & $\mathrm{H}$ \\
$\mathrm{L} 1-22$ & 2.4 & 10.4 & $\mathrm{H}$ & $\mathrm{H}$ \\
$\mathrm{L} 1-23$ & 2.4 & 6.3 & $\mathrm{H}$ & $\mathrm{H}$ \\
\hline $\mathrm{L} 1-24$ & 2.4 & 10.1 & $\mathrm{H}$ & $\mathrm{Pu}$ \\
$\mathrm{L} 1-25$ & 5.6 & 5.6 & $\mathrm{H}$ & $\mathrm{H}$ \\
$\mathrm{L} 1-26$ & 5.6 & 7.5 & $\mathrm{H}$ & $\mathrm{Pu}$ \\
$\mathrm{L} 1-29$ & 10.3 & 16.1 & $\mathrm{H}$ & - \\
\hline
\end{tabular}

"-" Not evaluated in time for the report

Table XII. Thermal Stability of PNNL Pu-Bearing LaBS Glasses.

\begin{tabular}{cccc}
\hline \hline Glass & $\mathrm{PuO}_{2}$ & $\mathrm{PuO}_{2}+\mathrm{UO}_{3}$ & Optical \\
\hline $\mathrm{L} 2-01$ & 2.4 & 10.1 & $\mathrm{H}$ \\
$\mathrm{L} 2-05$ & 8.7 & 12.6 & $\mathrm{Pu}$ \\
\hline $\mathrm{L} 2-06$ & 7.9 & 11.2 & $\mathrm{H}$ \\
$\mathrm{L} 2-07$ & 8.1 & 11.6 & $\mathrm{Pu}$ \\
$\mathrm{L} 2-08$ & 2.4 & 10.1 & $\mathrm{H}$ \\
$\mathrm{L} 2-10$ & 2.4 & 6.3 & $\mathrm{H}$ \\
\hline $\mathrm{L} 2-11$ & 5.6 & 11.3 & $\mathrm{Pu}$ \\
$\mathrm{L} 2-18$ & 8.7 & 8.7 & $\mathrm{Pu}$ \\
$\mathrm{L} 2-21$ & 7.1 & 11.0 & $\mathrm{Pu}$ \\
$\mathrm{L} 2-24$ & 5.6 & 9.4 & $\mathrm{Pu}$ \\
$\mathrm{L} 2-26$ & 5.6 & 13.2 & $\mathrm{Pu}$ \\
$\mathrm{L} 2-28$ & 5.6 & 7.5 & $\mathrm{H}$ \\
$\mathrm{L} 2-29$ & 5.6 & 9.4 & $\mathrm{Pu}$ \\
$\mathrm{L} 2-30$ & 5.6 & 9.4 & $\mathrm{H}$ \\
\hline
\end{tabular}


Table XIII. Devitrification Data of ANL Pu-Bearing LaBS Glasses.

\begin{tabular}{|c|c|c|c|c|c|c|}
\hline Glass & $\overline{\mathrm{PuO}_{2}}$ & $\mathrm{PuO}_{2}+\mathrm{UO}_{3}$ & Visual & Optical & SEM & Notes \\
\hline L3-02 & 2.4 & 2.4 & $\mathrm{H}$ & $\mathrm{H}$ & $\mathrm{n} / \mathrm{a}$ & 1 \\
\hline L3-07 & 2.4 & 9.4 & Pu expected & $\mathrm{H}$ & H & 2 \\
\hline L3-08 & 5.6 & 5.6 & $\mathbf{H}$ & $\mathrm{H}$ & $\mathrm{n} / \mathrm{a}$ & 1 \\
\hline L3-09 & 11.9 & 11.9 & Pu expected & Pu expected & $\mathrm{Pu}$ & \\
\hline L3-15 & 2.4 & 2.4 & $\mathbf{H}$ & $\mathrm{H}$ & $\mathrm{n} / \mathrm{a}$ & 1 \\
\hline L3-16 & 5.6 & 7.3 & Pu expected & $\mathrm{n} / \mathrm{a}$ & $\mathrm{Pu}$ & 3 \\
\hline L3-27 & 2.4 & 9.7 & $\mathbf{H}$ & $\mathrm{n} / \mathrm{a}$ & solids & 3,4 \\
\hline L3-30 & 8.7 & 10.5 & Pu expected & $\mathrm{n} / \mathrm{a}$ & $\mathrm{Pu}$ & 3,5 \\
\hline L3-04 & 6.6 & 8.9 & Pu expected & & & \\
\hline L3 $-05^{\dagger}$ & 5.6 & 9.1 & Pu expected & & & \\
\hline L $3-06^{\dagger}$ & 9.4 & 11.7 & Pu expected & & & \\
\hline L3-11 $1^{\dagger}$ & 8.1 & 11.3 & Pu expected & & & \\
\hline L3-13 ${ }^{\dagger}$ & 5.6 & 9.2 & $\mathbf{H}$ & & . & \\
\hline L3-23 ${ }^{\dagger}$ & 2.4 & 6.0 & $\mathbf{H}$ & & & \\
\hline
\end{tabular}

"Glasses considered as "acceptable" by ANL in terms of complete solubility (optical rating of 2 or less).

*Notes:

1 Glasses that were clear on optical were not examined by SEM - this noted as n/a (not applicable)

2 Although the glass underwent a color change, no $\mathrm{Pu}$ precipitates seen. Some $\mathrm{Zr}$ was observed on surface but does not appear to have precipitated from melt. Surface does have many small bubbles or holes that are several um across.

3 Glass not submitted for optical because chip was too thick (very dark color).

4 Appears to contain undissolved $\mathrm{Pu}$ (particles are spherical in shape)

5 Solids seen but were not identified; need to section and polish sample. A few of the particles may be $\mathrm{PuO}_{2}$. 


$$
\text { SRT-PUM-97-0017 }
$$

Table XIV. List of Homogeneous Glasses (no $\mathrm{PuO}_{2}$ devitrification . after heat treatment) with $\mathrm{PuO}_{2}+\mathrm{UO}_{3}$ loading $\geq 10 \mathrm{wt} \%$.

\begin{tabular}{|c|c|c|c|c|c|c|c|c|c|}
\hline $\begin{array}{l}\text { Glass } \\
\text { ID } \\
\text { L1-01 } \\
\text { L1-02 } \\
\text { L1-08 } \\
\text { L1-21 } \\
\text { L1-22 } \\
\text { L2-06 } \\
\text { L2-07 } \\
\text { L2-08 } \\
\text { L2-11 } \\
\text { L2-21 } \\
\text { L2-26 }\end{array}$ & $\begin{array}{l}\mathrm{PuO}_{2} \\
0.07975 \\
0.07268 \\
0.02400 \\
0.08076 \\
0.02400 \\
0.07975 \\
0.08076 \\
0.02400 \\
0.05550 \\
0.07125 \\
0.05550\end{array}$ & $\begin{array}{l}\mathrm{UO}_{3} \\
0.03247 \\
0.03601 \\
0.07700 \\
0.03514 \\
0.07700 \\
0.03247 \\
0.03514 \\
0.07700 \\
0.05780 \\
0.03855 \\
0.07700\end{array}$ & $\begin{array}{l}\text { Minor } \\
\text { Comp. } \\
0.01090 \\
0.02151 \\
0.00000 \\
0.01642 \\
0.01650 \\
0.01090 \\
0.01642 \\
0.00000 \\
0.02470 \\
0.02470 \\
0.03300\end{array}$ & $\begin{array}{l}\mathrm{SiO}_{2} \\
0.22744 \\
0.22390 \\
0.32100 \\
0.24071 \\
0.24850 \\
0.22390 \\
0.24071 \\
0.32100 \\
0.25780 \\
0.26130 \\
0.24850\end{array}$ & $\begin{array}{l}\mathrm{B}_{2} \mathrm{O}_{3} \\
0.09187 \\
0.09010 \\
0.07100 \\
0.09837 \\
0.10000 \\
0.09718 \\
0.09837 \\
0.12900 \\
0.08550 \\
0.08550 \\
0.10000\end{array}$ & $\begin{array}{l}\mathrm{Al}_{2} \mathrm{O}_{3} \\
0.17060 \\
0.17060 \\
0.13000 \\
0.18478 \\
0.19150 \\
0.17060 \\
0.18478 \\
0.13000 \\
0.16070 \\
0.16070 \\
0.13000\end{array}$ & $\begin{array}{l}\text { SrO } \\
0.01960 \\
0.01960 \\
0.01500 \\
0.02218 \\
0.02900 \\
0.01960 \\
0.02218 \\
0.02900 \\
0.01850 \\
0.01850 \\
0.02900\end{array}$ & $\begin{array}{l}\mathrm{ZrO}_{2} \\
0.01748 \\
0.01660 \\
0.03400 \\
0.02080 \\
0.03400 \\
0.01660 \\
0.02080 \\
0.00800 \\
0.01450 \\
0.01450 \\
0.02100\end{array}$ & $\begin{array}{l}\text { Rare } \\
\text { Earths } \\
0.34988 \\
0.34900 \\
0.32800 \\
0.30085 \\
0.27950 \\
0.34900 \\
0.30085 \\
0.28200 \\
0.32500 \\
0.32500 \\
0.30600\end{array}$ \\
\hline
\end{tabular}




$$
\text { SRT-PUM- } 97-0017
$$

\section{Thermal Stability (SRTC, PNNL, and ANL)}

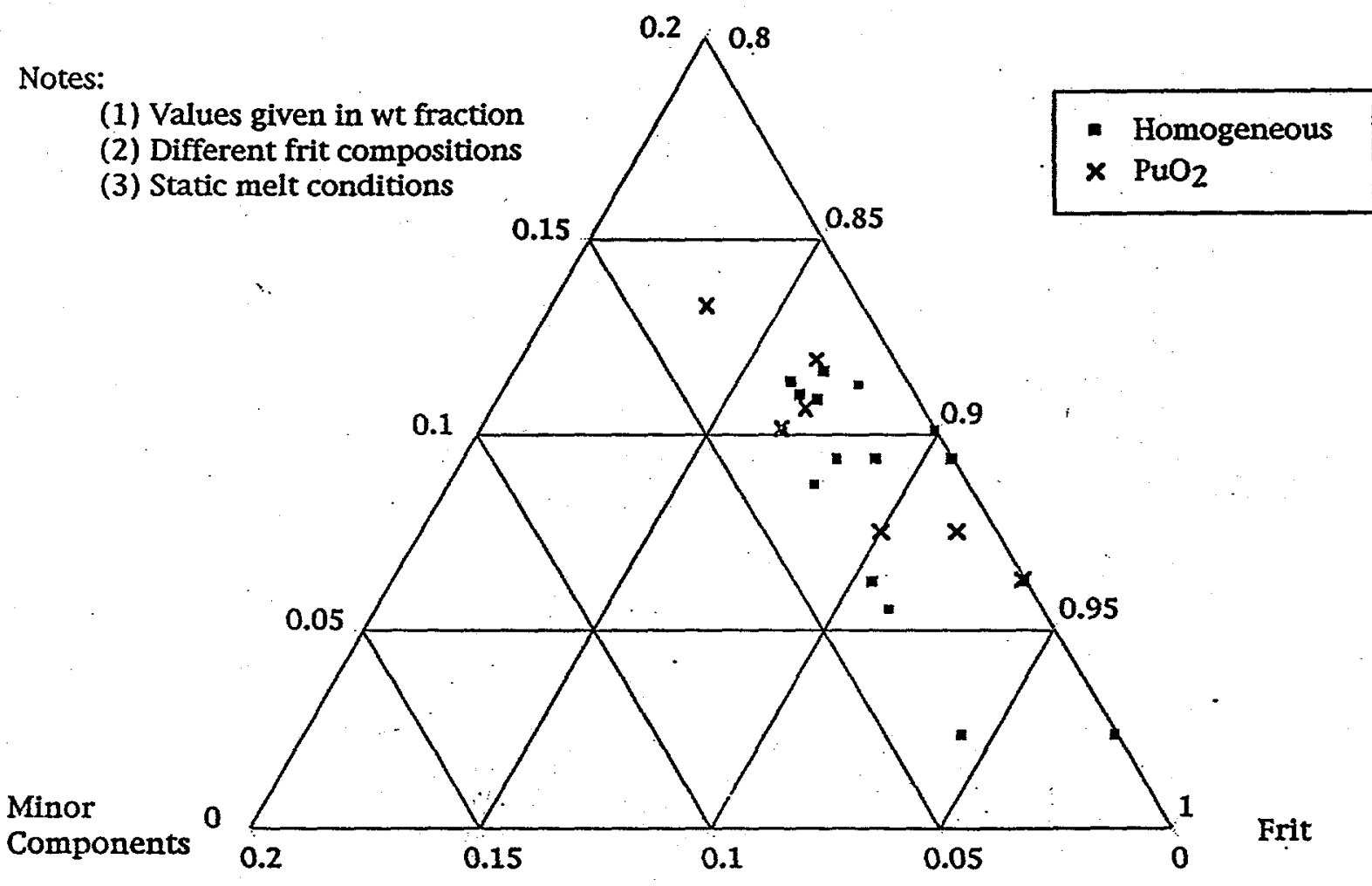

Figure 8. Thermal Stability of LaBS Glasses. 